\title{
Effects of Temperature and Moisture Content of Logs on Size Distribution of Black Spruce Chips Produced by a Chipper-canter at Two Cutting Widths
}

\author{
Imen Elloumi, ${ }^{\mathrm{a}, *}$ Roger E. Hernández, ${ }^{\mathrm{a}}$ Claudia B. Cáceres, ${ }^{\mathrm{a}}$ and Carl Blais ${ }^{\mathrm{b}}$ \\ Four matched groups of black spruce logs were processed with a chipper- \\ canter at temperatures of $20,0,-10$, and $-20^{\circ} \mathrm{C}$. Each log was transformed \\ at two moisture contents ( $\mathrm{MC}$, green and air-dried) using two cutting \\ widths (CW, 12.7 and $25.4 \mathrm{~mm}$ ). Mean MC for each CW was assessed \\ from a sample of the obtained chips. Knot characteristics were measured \\ on the cant surfaces after log processing. Chip size was assessed by \\ thickness (Domtar classifier) and width/length (Williams classifier). The \\ results showed that the chip size was significantly affected by the CW and \\ temperature, and in a lesser degree by the chip MC. The weighted mean \\ chip thickness (WCT) increased with the CW. As temperature decreased \\ below $0{ }^{\circ} \mathrm{C}$, WCT and accepts decreased, while proportions of fines and \\ pin chips increased. Chips obtained from green logs were thinner \\ compared to air-dried logs when processed at the coldest temperature \\ (minus $20^{\circ} \mathrm{C}$ ). The number and size of knots had an important impact on \\ chip size, particularly on WCT. Multiple regressions were developed to \\ predict WCT. Results showed the potential benefits of measuring log \\ temperature and knot features to reduce chip thickness variation during \\ fragmentation and thus improving chip size uniformity.
}

Keywords: Temperature; Moisture content; Cutting width; Chip size; Chipper-canter; Black spruce

Contact information: a: Centre de Recherche sur les Matériaux Renouvelables, Département des Sciences du Bois et de la Forêt, Université Laval, Pavillon Gene H.-Kruger, 2425 Rue de la Terrasse, GIV 0A6, QC, Canada; b: Département de Génie des Mines, de la Métallurgie et des Matériaux, Faculté des Sciences et de Génie, Université Laval, Pavillon Adrien-Pouliot, 1065 Avenue de la Médecine, GIV 0A6, QC, Canada;

*Corresponding author: roger.hernandez@sbf.ulaval.ca

\section{INTRODUCTION}

The forest industry has a major economic importance in Canada. In 2019, this industry contributed about 23.7 billion $\$ C A D$ to Canada's nominal gross domestic product (NRCAN 2020). The pulp and paper industries are some of the main users of Canada's wood fiber, producing approximatively $25 \%$ of the world's northern bleached softwood kraft pulp and 15\% of the world's newsprint paper (CIFQ 2014; Murnighan 2018).

In Quebec, sawmills are strongly integrated with the pulp and paper industries. About $61 \%$ of the raw material used for pulp production is supplied by sawmills, exclusively in the form of wood chips (Delisle 2019). The quality of chips directly affects their commercialization. Each pulping process has different requirements and specifications regarding chip quality, which is defined by several factors, such as bulk density, moisture content, bark content, wood species mixture, and chip dimensions (mean and distribution) (Bergman 1985). The optimal chip dimensions vary depending on the type of process, the equipment available, and the end-product (Hartler and Stade 1979). Chip thickness appears to be the most important parameter in mechanical pulping (Hoekstra et al. 1983), refiner-mechanical pulping, chemimechanical pulping (Lönnberg and Robertsén 1986), sulfite pulping (Feiner and Gallay 1962), and kraft pulping (Hatton and Keays 1973; Olson et al. 1980; Tikka et al. 1993). The chip size uniformity is another key factor that allows for the improvement in the quality of the pulping process (Pulkki 1991). For the 
purpose of this study, chip quality refers exclusively to the size of chips and their distribution.

Chipper-canters are widely used in eastern Canadian sawmills to transform small and medium diameter logs into cants and chips in a single operation. The most common chipper-canter has a truncated conical-shaped cutterhead fitted with uniformly distributed knife holders, each with a bent knife and a knife clamp. The bent knife has two cutting edges that are joined at an angle; a chipping edge to sever the slice to produce chips and a canting edge to smooth the cant. The performance of the chipper-canter is strongly influenced by the cutting parameters of the machine such as the design of the knife clamp (Hernández and Quirion 1993, 1995), the cutting speed (Hernández and Boulanger 1997), the log infeed position (Kuljich et al. 2017), and the inclination angle of the chipping edge (Grubîi et al. 2019). In addition, the cutting width (CW), closely associated to the log primary breakdown, is directly related to the resulting chip size. Thus, larger CWs will produce bigger chips (Hernández and Lessard 1997; Cáceres et al. 2015).

Wood properties also affect the performance of chipper-canters. The wood density, growth ring characteristics, and mechanical properties of the logs will influence the chip size (Cáceres et al. 2015, 2016). The knot features of logs have a large impact on chip dimensions (Cáceres et al. 2016, 2017). The log temperature during breakdown also affects the chip size distribution. In general, the logs are stored in the mill yard and have to cope with a variety of weather conditions throughout the year. Among seasons, processing logs during winter is more critical because their liquid water within them freezes and wood becomes stronger at temperatures below $0{ }^{\circ} \mathrm{C}$. The winter historical weather data in the Quebec province reported that the mean temperature ranged between 6 and $-30{ }^{\circ} \mathrm{C}$ from 1981 to 2010 (Quebec Government 2018). Accordingly, the wood temperature varied about $36{ }^{\circ} \mathrm{C}$ from December through March, at variable freezing rates depending on the local climate conditions of each year. Previous studies have reported that the thickness of pulp chips decreases when logs are processed under frozen conditions (Hernández and Boulanger 1997; Hernández and Lessard 1997; Kuljich et al. 2017; Grubîi et al. 2019). The volume of fines and pin chips can be two times greater when chipping frozen logs compared to unfrozen logs (Hernández and Quirion 1993). This behavior is associated with the variation of mechanical properties of wood as temperature decreases below $0{ }^{\circ} \mathrm{C}$. Hernández et al. (2014) found that cleavage and shear strength of black spruce increased $150 \%$ and $124 \%$, respectively, when green sapwood temperature decreased from 0 to -20 ${ }^{\circ} \mathrm{C}$. According to these authors, as the cleavage and shear strength increase with decreasing temperature, a small penetration of knife into the log would start fragmentation and thus thinner chips should be formed.

The moisture content (MC) of wood also has an effect in chip size, especially when processing green frozen logs. The time that $\operatorname{logs}$ are stored in the sawmill yards varies depending on the season, region, and $\log$ availability. As a result, there could be a great variation in the $\log \mathrm{MC}$, and this consequently would affect the size of chips. In general, the seasonal nature of supply can be characterized by the adequacy between the volume of wood delivered to the yard and the mill's consumption. Three seasons can be distinguished, inventory accumulation, inventory outflow, and a balanced season. The accumulation season is the one in which wood deliveries to the yard are greater than the mill's consumption. This season begins from late fall through late winter (Trzcianowska et al. 2019). During this period, the MC of the logs gradually decreases with a slow drying rate. For this reason, particular attention should be paid to the effect of $\mathrm{MC}$ when chipping frozen logs. Moreover, chip MC should not be lower than $36 \%$ on a dry-weight basis, according to sawmill quality standards in the Quebec province. Above the fiber saturation point (FSP), the proportion of frozen water in wood reinforces its strength (Mishiro and Asano 1984; Mishiro 1990; Hernández et al. 2014). This reinforcement will be higher when logs 
are in the green state (high MC), which will thus accentuate the effect of the freezing temperature on the chip size, depending on the amount of ice formed. According to Hernández and Lessard (1997), the high MC difference between heartwood and sapwood in softwoods would affect the chipping process in frozen conditions, depending on the CW. The greater proportion of ice in sapwood when using a small $\mathrm{CW}(12.7 \mathrm{~mm})$ played an important role in chip size distribution. As a result, sawmills should take into account the $\mathrm{MC}$ of logs during machining at temperatures below $0{ }^{\circ} \mathrm{C}$.

A better understanding of the chip size variation due to different log freezing temperatures and moisture contents will give sawmills the proper means to adequately adjust their cutting parameters to maintain chip size uniformity throughout the year. Under this context, this study evaluated the effects of log temperature and MC on size distribution of black spruce chips produced by a chipper-canter at two cutting widths.

\section{EXPERIMENTAL}

\section{Materials}

Tests were carried out with 60 freshly felled logs of black spruce [Picea mariana (Mill.) B.S.P.] from the region of Abitibi-Témiscamingue, in the Quebec province. Black spruce is one of the most important species in Canada and is mainly used for lumber and in a variety of secondary products. With its pale color, low resin content, and long and strong fibers, it is suitable for the manufacture of various types of pulps (Zhang and Koubaa 2008). The logs were crosscut to $2.5 \mathrm{~m}$ length and then freshly hand debarked. The crosscutting position was chosen to have a small end diameter of $158.8 \mathrm{~mm}$, which yielded a mean taper of $8 \mathrm{~mm} / \mathrm{m}$. The logs were without crook or visible decay. A $50-\mathrm{mm}$-thick disc was crosscut from each end of the log to measure wood physical properties. The logs and discs were wrapped in plastic films and stored green at $-19{ }^{\circ} \mathrm{C}$ until testing.

\section{Treatments}

Each log was chipped four times: at two moisture contents and two CWs: $12.7 \mathrm{~mm}$ and $25.4 \mathrm{~mm}$ (Fig. 1).

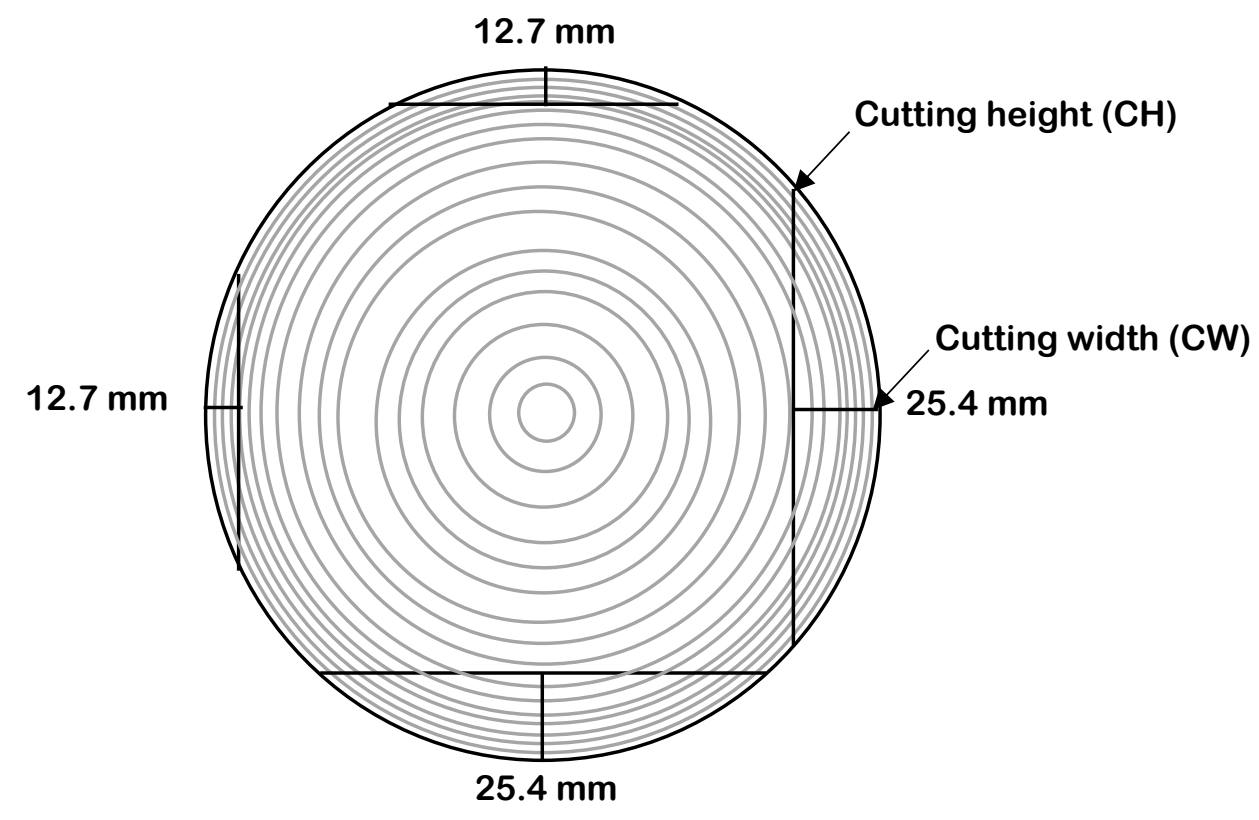

Fig. 1. Positions and dimensions of the $\mathrm{CW}$ of each segment in the small end of the log. The cutting height draws the segment area that will be fragmented. The cutting width is directly related to the area of chipping. 
The CW positions were selected according to best fitting in terms of log form and knottiness. The CWs were then marked down in both ends of each log and in its corresponding discs. Previous studies reported that mean sapwood thickness in black spruce is about 15 mm (Hernández and Lessard 1997; Kuljich et al. 2017; Grubîi et al. 2019). Therefore, the smaller cutting width should include only sapwood and the larger one was a combination of both sapwood and heartwood at different proportions, depending on each $\log$ diameter.

The first step of fragmentation was carried out with freshly felled logs, considered as the green condition. After that, the logs were coated with a sealer at both ends and at both cut sides to prevent a rapid moisture exchange. Logs were then air-dried during eight days in a conditioning chamber at $20{ }^{\circ} \mathrm{C}$ and $60 \%$ relative humidity. The second step of fragmentation was performed after air-drying. For these two steps, four temperatures were selected to assess the effect of log temperature on chip size, namely: $20,0,-10$, and $-20^{\circ} \mathrm{C}$. Fifteen logs were processed in each case.

\section{Sapwood Thickness, MC, and Basic Density Measurements}

Thickness of sapwood was measured at three positions on the four segments of the removed disc, which corresponded to each marked CW (Fig. 1). A cube of 25-mm-wide was then cut from each disc. The cubes were separated into sapwood and heartwood parts to determine $\mathrm{MC}$ and basic density (BD) separately. Thickness of these parts varied depending on the sapwood thickness of each log. The MC and BD were determined by the oven-drying method using ASTM D4442-16 (2016) and ASTM D2395-17 (2017), respectively. The sapwood MC was then used as the main criterion to separate the logs into four homogenous groups.

In addition, the MC of chips collected after fragmentation was determined to estimate the mean $\mathrm{MC}$ of the removed material from the logs. A sample of $100 \mathrm{~g}$ of chips was taken from each cutting condition to determine MC by the oven-drying method. This $\mathrm{MC}$ was more appropriate to assess the effect of this variable on the chip size distribution.

\section{Fragmentation Process}

Logs were processed with a laboratory prototype chipper-canter equipped with a DK-SPEC cutterhead (DK-SPEC Inc., Quebec, Canada) (Fig. 2). The cutterhead was fitted with eight freshly sharpened bent knives, made from steel A8 MOD, that are joined at an angle; a longer or chipping edge and a smaller or canting edge. The chipping edge had an angle of $30^{\circ}$ and a rake angle of $49^{\circ}$. The knife clamp angle was $35^{\circ}$ and the distance between the knife clamp edge and the knife edge was $22 \mathrm{~mm}$. The cutterhead was $631 \mathrm{~mm}$ in diameter, measured from one knife joint to the opposite one. The cutterhead position (vertical distance from the cutterhead axis to the bedplate) was fixed at $280 \mathrm{~mm}$ to obtain a mean attack angle (AA) of $88^{\circ}$ (angle between the chipping rake face and the wood grain) (Fig. 2). According to Kuljich et al. (2017), this corresponds to the infeed position of the $\log$, which should allow to obtain a chip thickness for unfrozen green $\operatorname{logs}$ of $5 \mathrm{~mm}$ at a cutting width of $25.4 \mathrm{~mm}$. The chipper-canter was equipped with a hydraulic feed carriage that held the log fixed with five clamps during fragmentation. The linear cutting speed was set at $23.5 \mathrm{~m} / \mathrm{s}$ at the junction point between the chipping and canting edges of knives. The rotation $(718 \mathrm{rpm})$ and feed $(146 \mathrm{~m} / \mathrm{min})$ speeds were adjusted to obtain a nominal chip length of $25.4 \mathrm{~mm}$.

As previously indicated, black spruce logs were processed at four temperatures and two CWs (Fig. 1). Because temperature of the chipper-canter laboratory varied between 18 and $22{ }^{\circ} \mathrm{C}$, great care had to be taken to preserve the temperature of the log during testing. Just prior to testing, every log was transferred from the freezing room to the laboratory into a Styrofoam box. The temperature of the log was then measured at two positions and at a 
depth of either 12.7 or $25.4 \mathrm{~mm}$, depending on the tested $\mathrm{CW}$. This was made using a digital thermometer to the nearest $0.1{ }^{\circ} \mathrm{C}$.

The CW (12.7 and $25.4 \mathrm{~mm}$ ) was kept constant throughout the log to better assess the effect of this variable on fragmentation (Fig. 1). This minimized the influence of log taper and cutting height $(\mathrm{CH})$ on chipping. The alignment of the $\mathrm{CW}$ along the log was made using a laser beam installed over the log carriage and by measuring it every $200 \mathrm{~mm}$ along the log until reaching the target $\mathrm{CW}$. To have a similar log infeed position $(280 \mathrm{~mm})$ for each $\mathrm{CW}$ in the same $\log$ (Fig. 1), the width of the previously removed chipped side was replaced by placing a board of the same thickness $(12.7$ or $25.4 \mathrm{~mm})$ under the $\log$ before chipping the next condition. After each fragmentation, all chips produced were collected in plastic bags. Cants were wrapped with polyethylene and stored in a $-19{ }^{\circ} \mathrm{C}$ freezer along with chip bags for further analysis.

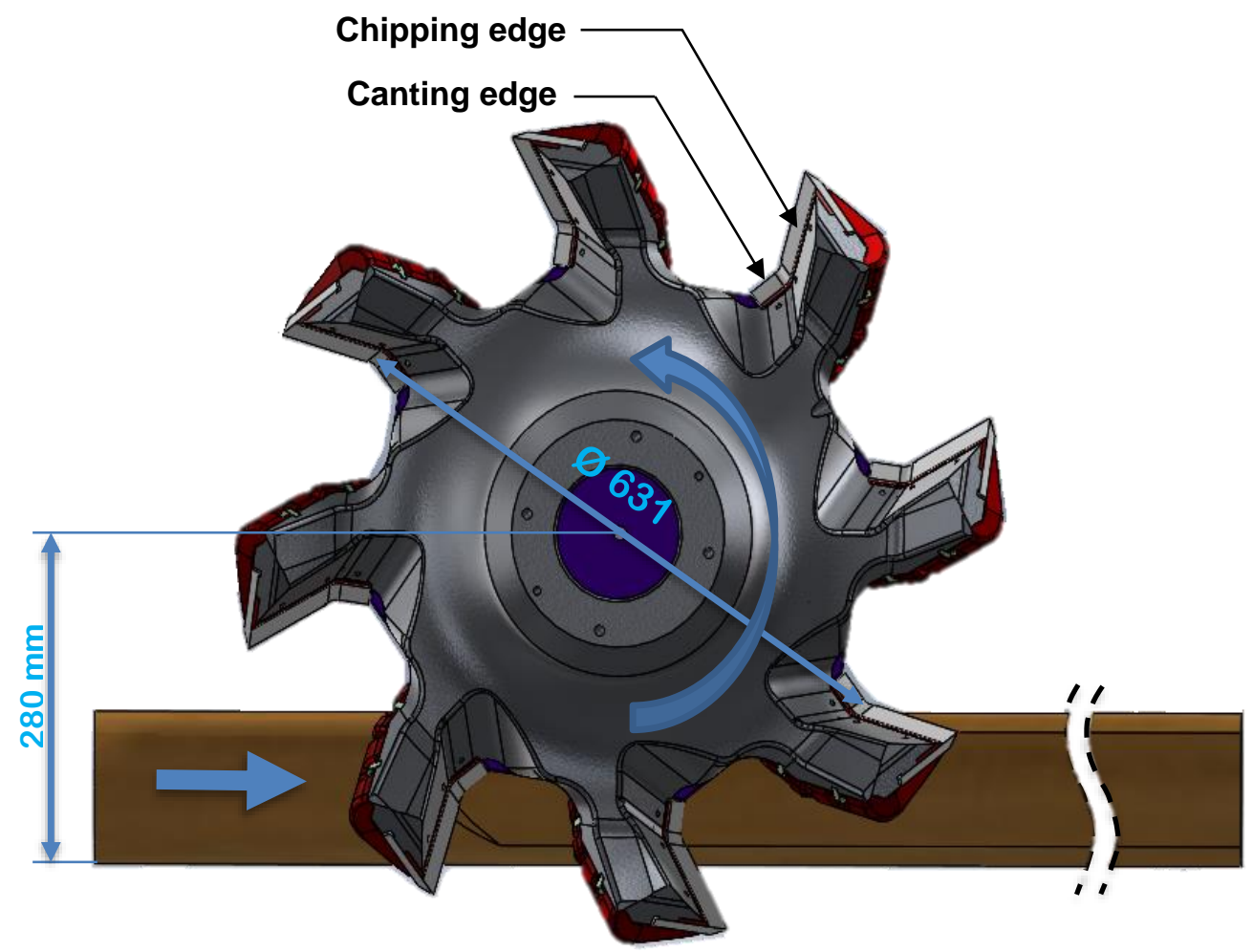

Fig. 2. Back view of DK-SPEC cutterhead provided with eight bent knives, showing the log infeed position used for the tests

\section{High-speed Photography}

A high-speed camera was installed below the cutterhead to visualize in real time the cutting action of the chipper-canter. The chip formation mechanism was recorded for 2 logs per cutting condition. Videos were taken with a "MotionPro Y4-S3" camera (Integrated Design Tools (IDT), Tallahassee, FL, USA) fitted with a $35 \mathrm{~mm} / \mathrm{f} 1.4$ lens (Kowa, Osaka, Japan) at a frequency of $3000 \mathrm{frames} / \mathrm{s}$ and an exposure time of $22 \mu \mathrm{s}$. The focus was done on the rake face of the knives. The images were acquired with Motion Studio software (IDT, Tallahassee, FL, USA) at a maximum resolution $(1024 \times 1024$ pixels).

\section{Chip Classification}

Chips were air-dried indoors for 2 weeks to facilitate their separation. A representative sample of about $2 \mathrm{~kg}$ from each cutting condition was taken using a Domtar separator (Fort Mill, SC, USA) when necessary. The chip size distribution was then 
evaluated by two methods using Domtar and Williams classifiers. The Domtar classifier separates chips according to thickness (into $2 \mathrm{~mm}$ classes) and length. Chip categories retained with this classifier were: fines (material that passes a $4.5 \mathrm{~mm}$ diameter hole screen); fragile chips (under 2-mm-thick chips, minus fines); accepts (over $2 \mathrm{~mm}$ thick by $2 \mathrm{~mm}$ classes up to $8 \mathrm{~mm}$ ); overthicks (over $8 \mathrm{~mm}$ thick by $2 \mathrm{~mm}$ classes up to $18 \mathrm{~mm}$, over $18 \mathrm{~mm}$ ), and oversize (the fraction retained on a $45-\mathrm{mm}$ diameter hole screen).

The Williams classifier sorts chips by width and length in the following classes: fines (material that passes a 4.8-mm diameter screen hole); pin chips (material retained in a $4.8-\mathrm{mm}$ diameter screen hole); $9.5 \mathrm{~mm}$ or small chips (material retained in a $9.5-\mathrm{mm}$ diameter screen hole); accept chips (chips retained in screens of 15.9, 22.2, and $28.6 \mathrm{~mm}$ of hole diameter); and oversize chips (the fraction retained by the $45-\mathrm{mm}$ diameter screen hole).

The chip classes obtained with both classifiers follow the dimensions required by the Canadian pulp and paper industries. Sawmills aim to maximize the chip volume of the accept class and minimize the volume of the other classes.

\section{Knot Assessment}

Knots were assessed on the cant surfaces obtained after log fragmentation. Each surface was scanned with a portable scanner GoScan 50 (Creaform, Lévis, Canada) at a resolution of $0.9 \mathrm{~mm}$. The scanner is based on triangulation of fascicles of white light to capture the surface in full color. The image obtained was processed with VXmodel software to remove the edges and have a 3D image of the cant surface. All knots larger than $2 \mathrm{~mm}$ were evaluated. The knot parameters measured with the software included the total knot number on the cant surface (TKN) and the total knot area (TKA) (sum of the area of all knots on the cant surface).

\section{Statistical Analysis}

Data were analyzed using Statistical Analysis System (SAS) 9.4 software (SAS Institute Inc., Cary, NC, USA). The experiment followed a split-plot design. The temperature was the source of variation in the main plot. Moisture content and cutting width were the sources of variation in the subplot. The moisture content of chips was nested within the cutting width, since this parameter was specific to each CW. Raw data were first evaluated with the Box-Cox method showing the more fitted transformation if required. For all analyses, knot characteristics and wood physical properties were used as covariates, keeping only those that were significant for each model. First, a mixed model of analysis of covariance (ANCOVA) was used to evaluate the weighted mean chip thickness (WCT). Then, a multivariate analysis of covariance (MANCOVA) was performed using the Aitchison approach of compositional data (Aitchison 1982) for the Domtar and Williams chip class distributions. This approach uses one of the chip classes as a reference and works with the proportion of each of the other classes as a function of the reference. Hence, compositional data analysis takes into account the existing dependence among the classes as they function as a whole, and therefore, when one class increases, another has to decrease to maintain the same whole. However, this compositional data analysis does not allow comparisons of the real values of each class because it works with proportions. Consequently, an ANCOVA of each class was performed individually. Afterwards, a multiple linear stepwise regression was done to determine if the principal sources of variation (temperature, $\mathrm{MC}$, and $\mathrm{CW}$ ) and the measured covariates were good predictors of WCT. Finally, the normality was verified with Shapiro-Wilk's test, and the homogeneity of variance was verified with the graphical analysis of residuals. Statistical significance was tested at 5 and $1 \%$ probability levels. 


\section{RESULTS AND DISCUSSION}

The mean properties of the four groups of black spruce logs are given in Table 1. The ANOVAs (not shown) revealed that the mean values of MC and BD for sapwood and heartwood, as well as sapwood thickness, and log taper were similar for all groups of logs. Moisture content of freshly felled logs was significantly higher for sapwood (110\%) than for heartwood (42\%). Similar values of green MC have been reported for black spruce logs from Eastern Canada (Hernández and Quirion 1993; Hernández and Boulanger 1997; Hernández and Lessard 1997; Kuljich et al. 2017; Grubîi et al. 2019). However, BDs of sapwood $\left(461 \mathrm{~kg} / \mathrm{m}^{3}\right)$ and heartwood $\left(455 \mathrm{~kg} / \mathrm{m}^{3}\right)$ were not statistically different. The mean $\mathrm{BD}$ of $458 \mathrm{~kg} / \mathrm{m}^{3}$ was in the highest limit of the BD range (399 to $461 \mathrm{~kg} / \mathrm{m}^{3}$ ) found in previous studies on this species in Eastern Canada (Hernández and Boulanger 1997; Hernández and Lessard 1997; Hernández et al. 2014; Cáceres et al. 2016; Kuljich et al. 2017; Grubîi et al. 2019; Kharrat et al. 2021). Density variation can be associated with environmental and genetic factors, including the geographic location, site conditions, and tree age (Miles and Smith 2009). Moreover, knot characteristics depended on the CW. The total knot number increased as $\mathrm{CW}$ increased. In fact, a greater $\mathrm{CW}$ generated a bigger cant surface resulting a higher number of visible knots. Accordingly, the total knot area also increased with the larger CW. A knot is the base of a branch that has been embedded in the tree stem as the tree grows in diameter (Tong et al. 2013). With time, some of the branches die, decay, fall off and become overgrown. These knots will be visible only when the log is sawn or split (Jozsa and Middelton 1994).

Table 1. Characteristics of Black Spruce Logs Used for Each Studied Cutting Condition

\begin{tabular}{|c|c|c|c|c|c|c|c|c|}
\hline \multirow{3}{*}{$\begin{array}{c}\text { Log Charac- } \\
\text { teristics }\end{array}$} & \multicolumn{8}{|c|}{ Temperature $\left({ }^{\circ} \mathrm{C}\right)$} \\
\hline & \multicolumn{4}{|c|}{ Before Air-drying } & \multicolumn{4}{|c|}{ After Air-drying } \\
\hline & $\begin{array}{c}1^{a} \\
\left(-20^{\circ} \mathrm{C}\right)\end{array}$ & $\begin{array}{c}2 \\
\left(-10^{\circ} \mathrm{C}\right)\end{array}$ & $\begin{array}{c}3 \\
\left(0^{\circ} \mathrm{C}\right)\end{array}$ & $\begin{array}{c}4 \\
\left(20^{\circ} \mathrm{C}\right)\end{array}$ & $\begin{array}{c}1 \\
\left(-20^{\circ} \mathrm{C}\right)\end{array}$ & $\begin{array}{c}2 \\
\left(-10^{\circ} \mathrm{C}\right)\end{array}$ & $\begin{array}{c}3 \\
\left(0^{\circ} \mathrm{C}\right)\end{array}$ & $\begin{array}{c}4 \\
\left(20^{\circ} \mathrm{C}\right)\end{array}$ \\
\hline \multicolumn{9}{|c|}{ Moisture Content (\%) } \\
\hline $\begin{array}{l}\text { Sap- } \\
\text { wood }\end{array}$ & $108(6)^{b}$ & $113(4)$ & $115(4)$ & $105(5)$ & $62(5)$ & $87(4)$ & $86(4)$ & $65(5)$ \\
\hline Heartwood & $40(1)$ & $42(2)$ & $43(2)$ & $44(2)$ & $33(1)$ & $34(1)$ & $36(1)$ & $33(1)$ \\
\hline \multicolumn{9}{|c|}{ Sapwood Thickness (mm) } \\
\hline $12.7^{c}$ & $\begin{array}{l}16.1 \\
(0.7)\end{array}$ & $\begin{array}{l}15.6 \\
(0.6)\end{array}$ & $\begin{array}{l}15.7 \\
(0.7)\end{array}$ & $\begin{array}{l}16.1 \\
(0.5)\end{array}$ & $\begin{array}{l}15.4 \\
(0.6)\end{array}$ & $\begin{array}{l}15.3 \\
(0.7)\end{array}$ & $\begin{array}{l}15.5 \\
(0.7)\end{array}$ & $\begin{array}{l}15.4 \\
(0.5)\end{array}$ \\
\hline 25.4 & $\begin{array}{l}16.5 \\
(0.8)\end{array}$ & $\begin{array}{l}15.6 \\
(0.5)\end{array}$ & $\begin{array}{l}15.8 \\
(1.0)\end{array}$ & $\begin{array}{l}15.7 \\
(0.6)\end{array}$ & $\begin{array}{l}15.1 \\
(0.6)\end{array}$ & $\begin{array}{l}15.1 \\
(1.0)\end{array}$ & $\begin{array}{l}15.1 \\
(0.7)\end{array}$ & $\begin{array}{l}15.9 \\
(0.6)\end{array}$ \\
\hline \multicolumn{9}{|c|}{ Total Knot Number d } \\
\hline 12.7 & $13(2)$ & $15(1)$ & $12(1)$ & $15(1)$ & $15(2)$ & $14(1)$ & $17(1)$ & $16(2)$ \\
\hline 25.4 & $24(2)$ & $21(2)$ & $24(2)$ & $22(1)$ & $26(1)$ & $23(2)$ & $25(1)$ & $23(1)$ \\
\hline \multicolumn{9}{|c|}{ Total Knot Area $\left(\mathrm{mm}^{2}\right)^{d}$} \\
\hline 12.7 & $\begin{array}{c}462 \\
(144)\end{array}$ & $\begin{array}{c}745 \\
(195) \\
\end{array}$ & $\begin{array}{l}481 \\
(65)\end{array}$ & $\begin{array}{l}541 \\
(99)\end{array}$ & $\begin{array}{c}650 \\
(118)\end{array}$ & $\begin{array}{l}532 \\
(91) \\
\end{array}$ & $\begin{array}{c}942 \\
(125)\end{array}$ & $\begin{array}{l}632 \\
(93) \\
\end{array}$ \\
\hline 25.4 & $\begin{array}{l}1111 \\
(182)\end{array}$ & $\begin{array}{l}1167 \\
(197)\end{array}$ & $\begin{array}{l}1458 \\
(144)\end{array}$ & $\begin{array}{l}1140 \\
(293)\end{array}$ & $\begin{array}{l}1378 \\
(193)\end{array}$ & $\begin{array}{l}1137 \\
(241)\end{array}$ & $\begin{array}{l}1729 \\
(209)\end{array}$ & $\begin{array}{c}992 \\
(152)\end{array}$ \\
\hline $\begin{array}{l}\text { a Groups } 1 \text { th } \\
\text { b Numbers in } \\
{ }^{c} \text { Cutting widt } \\
{ }^{d} \text { Property m }\end{array}$ & gh 4 we & $\begin{array}{l}\text { ested a } \\
\text { re the } \\
\text { h proce }\end{array}$ & vo moist & $\begin{array}{l}\text { conter } \\
\text { sace }\end{array}$ & $\begin{array}{l}\text { before } \\
\text { ean; }\end{array}$ & after a & & \\
\hline
\end{tabular}




\section{Chip Formation}

High-speed images show the influence of log temperature and cutting width on the formation of chips at green condition (Fig. 3).
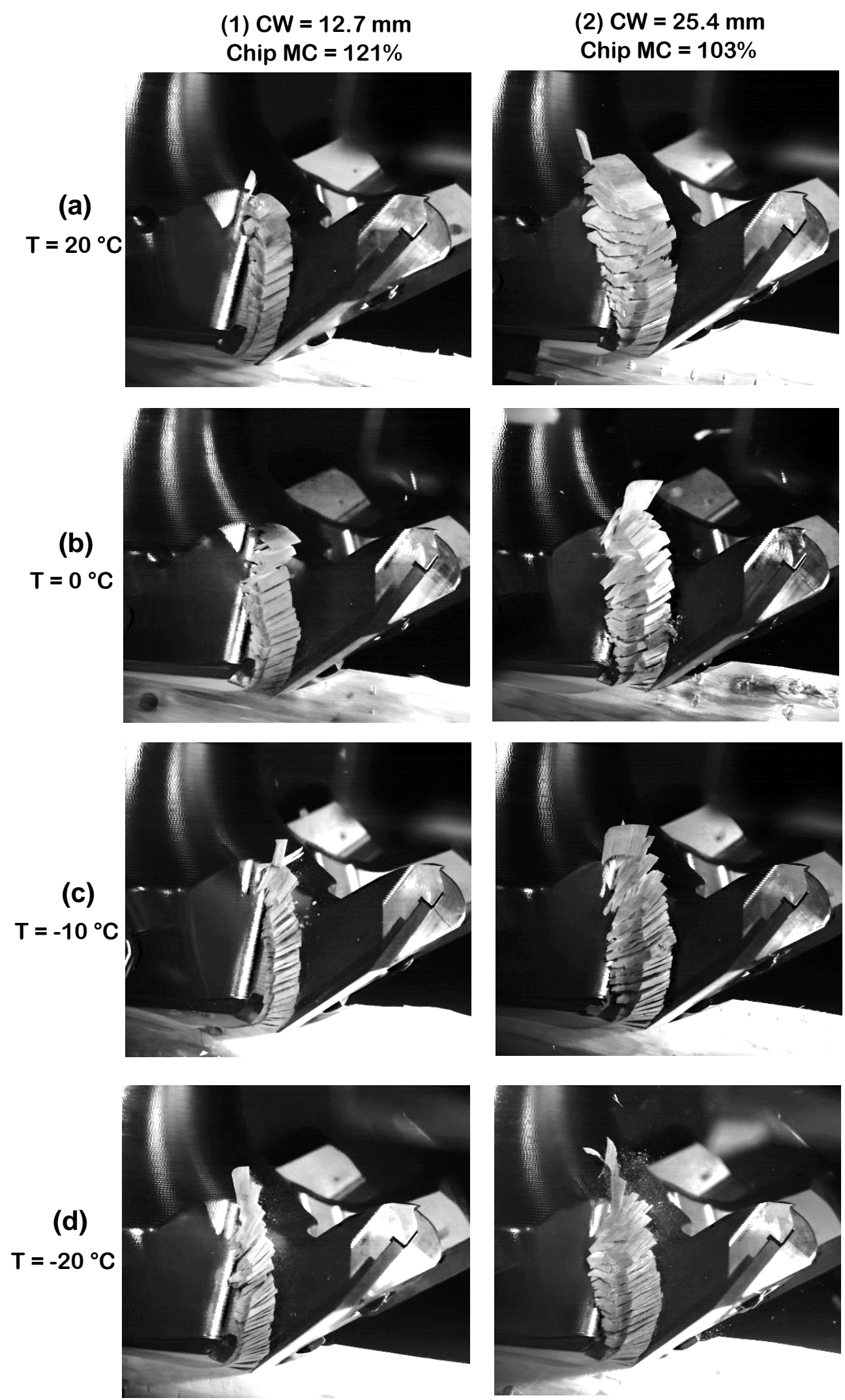

Fig. 3. Progression of the slice fragmentation produced by the chipping edge for two cutting widths (CW) (1) $12.7 \mathrm{~mm}$ and (2) $25.4 \mathrm{~mm}$ at four wood temperatures (T) 
The formation of chips by the chipper-canter has been described in previous works (Kuljich et al. 2017; Grubîi et al. 2019). The chipping edge cut the wood obliquely to the grain while, simultaneously, the canting edge smoothed the cant surface as it traveled across the grain. Chip formation involved at least two different cutting actions. At the entry point of the knife into the log, the chipping edge compressed the wood obliquely to the grain. The knife then penetrated the log, severing a slice by shearing obliquely to the grain. The feed per knife determines the thickness of the slice, which, after chipping, will correspond to the length of the chips. As the wood slice was formed, it underwent stresses in the parallel and oblique grain directions due to the compression induced by the rake face of the chipping edge. This resulted in a continuous fragmentation of the slice. Accordingly, depending on the attack angle formed between the chipping rake face and the wood grain, chips can be produced by splitting or by shearing parallel to the grain (Kuljich et al. 2017). In the present study, chips were mostly produced by splitting, which was desirable because this situation requires less cutting energy.

The high-speed images also showed that as wood temperature decreased from $0{ }^{\circ} \mathrm{C}$ to $-20{ }^{\circ} \mathrm{C}$, the chip thickness progressively decreased for both $\mathrm{CWs}$, as well as for green logs (Fig. 3) and for air-dried logs. At temperatures below $0{ }^{\circ} \mathrm{C}$, a portion of the $\mathrm{MC}$ transforms into ice (free water), while another portion remains in a non-freezing condition (non-freezing bound water) (Li et al. 2019). Ordinary ice exhibits brittle behavior under compression at high deformation rates (Schulson 2001; Petrenko and Withworth 2002). Thus, it can be inferred that the presence of ice in green wood during fragmentation increased its brittleness, which means that it would fracture more suddenly with little tendency to deform before rupture. Therefore, chipping by splitting occurred more regularly, resulting in thinner chips. This behavior was amplified as the temperature got colder, which can be associated to the portion of bound water that becomes frozen as higher sub-zero temperatures are reached (freezing bound water) (Telkki et al. 2013; Guo et al. 2018; Li et al. 2019).

In contrast, the cutting width directly affects the wood area in contact with the chipping rake face. As previous studies have reported, a smaller cutting width decreases the split-area in the slice cut by each chipping knife (Fig. 1). Thus, the splitting strength required for chip formation will be more regularly reached, producing thinner chips. In contrast, thicker chips would be obtained with higher cutting widths (Hernández and Lessard 1997; Cáceres et al. 2015, 2016, and 2017).

\section{Weighted Mean Chip Thickness}

A first analysis of chips sieved by the Domtar classifier can be performed by means of the weighted mean chip thickness (WCT) statistic, which was calculated by using the median value for each $2 \mathrm{~mm}$ thickness class separated by the classifier. The expected chip thickness for unfrozen green wood was $5 \mathrm{~mm}$, the median value for the acceptable fraction at a cutting width of $25.4 \mathrm{~mm}$ obtained at $88^{\circ}$ of attack angle (Kuljich et al. 2017). The obtained WCT was $5.10 \mathrm{~mm}$ (Table 5), which confirms that this angle is a good alternative to adequately control the thickness of pulp chips.

The ANCOVA showed that WCT was affected by the cutting width and log temperature. The F-values showed that the $\mathrm{CW}$ had the greatest effect on the chip thickness (Table 2). Thus, chips were thinner for the smaller $\mathrm{CW}$ for all temperatures and moisture contents (Fig. 4). As explained before, the CW directly affects the area of chipping, and therefore the thickness of the chips. This is in agreement with previous studies on the effect of CW on WCT in black spruce logs (Hernández and Lessard 1997; Cáceres et al. 2015, 2016, 2017). 
Table 2. F-Values Obtained by the Compositional Data ANCOVA of Domtar and Williams Chip Class Distributions and of Weighted Mean Chip Thickness

\begin{tabular}{|c|c|c|c|}
\hline Source of Variation & $\begin{array}{c}\text { Domtar Chip } \\
\text { Classes }\end{array}$ & $\begin{array}{l}\text { Williams Chip } \\
\text { Classes }\end{array}$ & $\begin{array}{l}\text { Weighted Mean } \\
\text { Chip Thickness }\end{array}$ \\
\hline Total knot area (TKA) & $42.6^{\star *}$ & $2.9^{*}$ & $37.9^{\star \star}$ \\
\hline Total knot number (TKN) & $9.4^{* *}$ & $4.8^{* *}$ & $13.3^{\star *}$ \\
\hline Sapwood mean thickness (ST) & - & - & $7.4^{\star \star}$ \\
\hline Temperature $(T)$ & $71.1^{* *}$ & $59.8^{* *}$ & $154.5^{\star *}$ \\
\hline Cutting width (CW) & $115.2^{* *}$ & $56.1^{* *}$ & $392.5^{* *}$ \\
\hline$T^{\star} \mathrm{CW}$ & $6.7^{* *}$ & $5.5^{\star *}$ & $1.8 \mathrm{~ns}$ \\
\hline [Moisture content $(\mathrm{CW})]$ & $3.5^{\star \star}$ & $3.0^{* *}$ & $1.5 \mathrm{~ns}$ \\
\hline$T^{*} \mathrm{MC}{ }^{*} \mathrm{CW}$ & $1.6^{*}$ & $0.7 \mathrm{~ns}$ & $3.1^{* *}$ \\
\hline
\end{tabular}

The effect of log temperature on WCT was also important (Table 2). The WCT decreased as log temperature decreased below $0{ }^{\circ} \mathrm{C}$ (Fig. 4). In addition, WCT was similar between 20 and $0{ }^{\circ} \mathrm{C}$, which is in agreement with the mechanical behavior of wood (Hernández et al. 2014). The decrease of WCT with temperature below $0{ }^{\circ} \mathrm{C}$ is associated with changes in the mechanical properties when the wood is frozen. Cáceres et al. (2015, 2016, 2017) reported that the modulus of rupture, modulus of elasticity, splitting, and shear strengths are greatly involved in the chipping process. A previous study on black spruce wood at $139 \% \mathrm{MC}$, stated that these properties increased as the temperature decreased from 0 to $-20{ }^{\circ} \mathrm{C}$, but they showed different sensitivity to the temperature drop (Hernández et al. 2014). Accordingly, their combined effect would be different depending on the freezing temperature, resulting in chip size variation. In addition, the presence of ice increased the brittleness of the frozen logs (Koran 1979; Schulson 2001; Petrenko and Withworth 2002; Zhao et al. 2015). Thus, as the chipping edge compressed the wood, smaller/thinner chips were generated (Fig. 3d). This behavior would be more pronounced at colder sub-zero temperatures.

The decrease of WCT from $20{ }^{\circ} \mathrm{C}$ to $-20{ }^{\circ} \mathrm{C}$, obtained at $25.4 \mathrm{~mm}$ of CW with logs at green condition, was $1 \mathrm{~mm}$ (Table 5). Kuljich et al. (2017) also obtained $1 \mathrm{~mm}$ of WCT difference using the same cutting parameters, even though the log temperature varied between 18 and $-25^{\circ} \mathrm{C}$. It could be expected to obtain a smaller WCT decrease because the sub-zero temperature range was $5{ }^{\circ} \mathrm{C}$ lower. However, the similar WCT decrease between these two studies might be attributed to the effect of wood density in chip formation. According to Cáceres et al. (2015), higher wood density would result in thinner chips. Mean basic density in the present work was higher $\left(458 \mathrm{~kg} / \mathrm{m}^{3}\right)$ compared to Kuljich et al. (2017) $\left(441 \mathrm{~kg} / \mathrm{m}^{3}\right)$, which could account for the similar chip thickness decrease at different ranges of sub-zero log temperatures. This demonstrates that fragmentation is a complex process that can be affected by the wood properties and, therefore, it should be closely monitored to assure a proper chip size consistency.

Moreover, a statistically small but significant three-way interaction affected WCT (Table 2), indicating that the effect of temperature varied depending on the $\mathrm{CW}$ and $\mathrm{MC}$. Accordingly, the results showed that at green condition, the difference in WCT between 20 ${ }^{\circ} \mathrm{C}$ and $-20{ }^{\circ} \mathrm{C}$ was $1.11 \mathrm{~mm}$ at $12.7 \mathrm{~mm}$ of $\mathrm{CW}$, while it was $1.00 \mathrm{~mm}$ at $25.4 \mathrm{~mm}$ of $\mathrm{CW}$. For the air-dry condition, this difference was $0.79 \mathrm{~mm}$ for the smaller $\mathrm{CW}$ and $0.61 \mathrm{~mm}$ for the larger CW (Table 5). This behavior is related to the difference in MC between the green and the air-dry conditions at the two studied CWs. Each cutting width had an intrinsic MC represented by the proportions of sapwood and heartwood combined in it. As explained earlier, at $12.7 \mathrm{~mm}$ of $\mathrm{CW}$, almost $100 \%$ of the slice volume was sapwood. At $25.4 \mathrm{~mm}$ of 
$\mathrm{CW}$, the slice included a certain volume of heartwood. This resulted in $121 \%$ and $79 \% \mathrm{MC}$ for the smaller $\mathrm{CW}$ and $103 \%$ and $67 \% \mathrm{MC}$ for the larger $\mathrm{CW}$, at green and air-dry conditions, respectively. Consequently, a greater effect of temperature on mechanical properties (i.e., splitting) should be found in green wood (Mishiro and Asano 1984; Mishiro 1990; Hernández et al. 2014; Zhao et al. 2015) compared to air-dried wood, due to the higher amount of ice formed in the logs. Accordingly, Fig. 4 shows that at $-20{ }^{\circ} \mathrm{C}$, processing logs with a CW of $12.7 \mathrm{~mm}$, increased WCT from 3.24 to 3.56 when MC decreased from $121 \%$ to $79 \%$. Similarly, at $-20{ }^{\circ} \mathrm{C}$, processing logs with $25.4 \mathrm{~mm}$ of $\mathrm{CW}$ resulted in an increase of WCT from 4.10 to $4.38 \mathrm{~mm}$ when MC decreased from $103 \%$ to $67 \%$. As described earlier, the logs harvested in late fall and in winter will be stored in the log yard for several months before sawing (Trzcianowska et al. 2019); therefore a slow log air-drying process is set off. From a practical point of view, it seems that this log storage under colder sub-zero temperatures $\left(\geq-20^{\circ} \mathrm{C}\right)$ during winter could potentially reduce the effect of temperature on WCT.

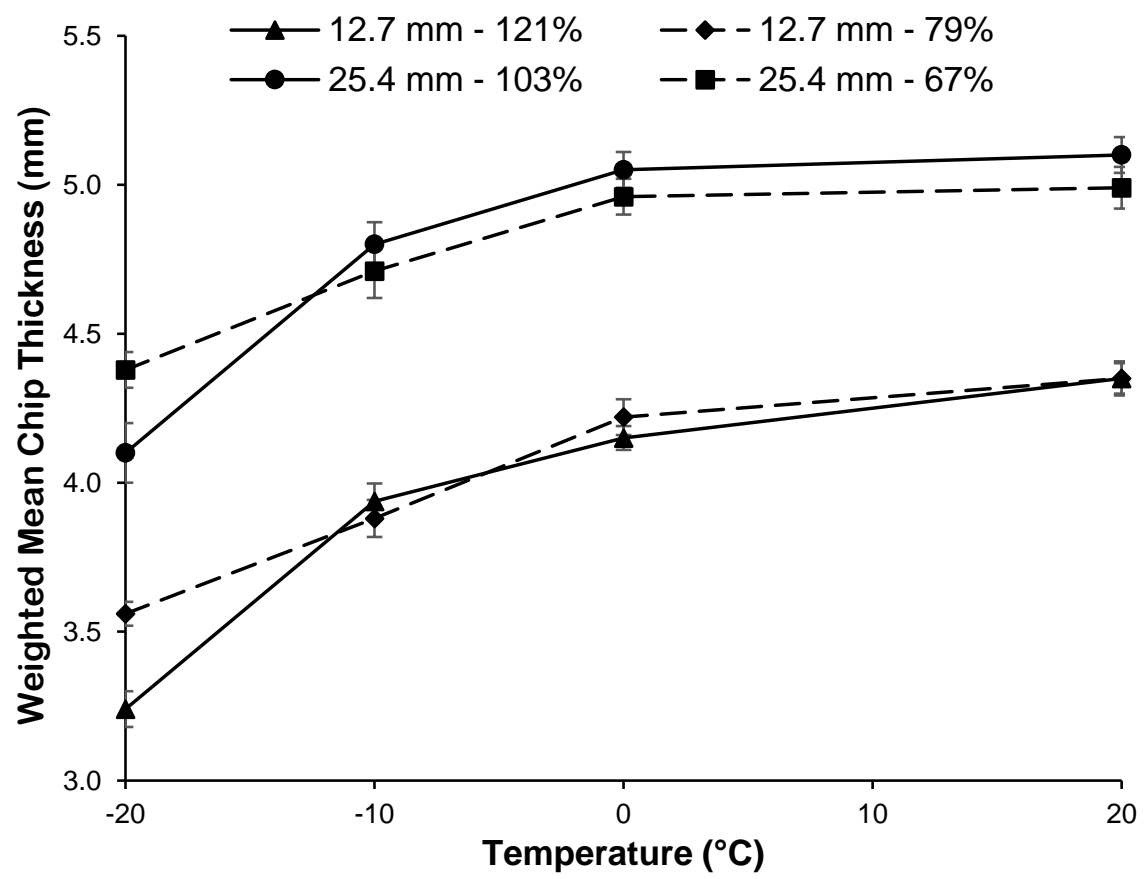

Fig. 4. Weighted mean thickness of black spruce chips as a function of wood temperature for two cutting widths and two chip moisture contents. Bars represent the standard error.

However, the difference in WCT between the two MCs for each CW was not statistically significant when $\operatorname{logs}$ were at $-10{ }^{\circ} \mathrm{C}$. These results can be partially attributed to the strengthening effect of $\mathrm{MC}$ at higher sub-zero temperatures on mechanical properties of green wood (Hernández et al. 2014). The splitting strength was estimated for each studied condition using the regression equation developed by Hernández et al. (2014) (not shown). The difference in splitting strength between green and air-dried MCs was approximately two times higher at $-20{ }^{\circ} \mathrm{C}$ compared to $-10{ }^{\circ} \mathrm{C}$. This indicates that the difference in mechanical properties generated by the decrease of $\mathrm{MC}$ at $-10{ }^{\circ} \mathrm{C}$ would not suffice to alter the WCT. Moreover, the inherent freezing process of water inside a wood species could also affect its mechanical properties and consequently the WCT. The wood porosity, the difference in the properties of the water in macroscopic and microscopic interstices, the interaction forces between the water and the capillary walls, and the minerals and organic substances dissolved in the water affect the wood freezing process (Torgovnikov 1993). Below the freezing point of bulk water, wood's free water is frozen (MC above FSP, in the cell lumen) (Telkki et al. 2013). For bound water (MC below FSP, 
in the cell wall), there is a portion that remains unfrozen and another one that can be further frozen as higher sub-zero temperatures are reached. This portion will vary with the species because the freezing-point depression is proportional to the pore size (Telkki et al. 2013; Gao et al. 2015; Li et al. 2019). For example, previous studies on Pinus sylvestris reported that $17 \%$ of bound water can be frozen at $-20{ }^{\circ} \mathrm{C}$ compared to $5 \%$ at $-10{ }^{\circ} \mathrm{C}$ (Gao et al. 2015). Furthermore, the stiffening effect of ice in wood would be stronger as more bound water is frozen within the cell wall (Koran 1979). It would follow that at higher sub-zero temperatures $\left(\geq-20^{\circ} \mathrm{C}\right)$ the proportion of frozen bound water would significantly increase, reinforcing the strength of wood and thus reducing WCT. Seemingly, this would not take place at lower sub-zero temperatures $\left(-10^{\circ} \mathrm{C}\right)$. Further studies should be done to fully understand the behavior of WCT in the range of sub-zero temperatures between $-10{ }^{\circ} \mathrm{C}$ and $-20{ }^{\circ} \mathrm{C}$ for black spruce wood.

In addition, the covariates that significantly affected WCT were in order of importance (F-value), total knot area (TKA), total knot number (TKN), and sapwood mean thickness (ST) (Table 2). Both TKA and TKN had good correlations with WCT ( $\mathrm{r}=0.49$, $r=0.54$, respectively, all data pooled). The weighted mean chip thickness increased as TKA increased (Fig. 5). Thus, as knots covered a larger area of the cant face, thicker chips were produced. A more explicit impact of TKA on WCT can be observed in Fig. 4. For a cutting width of $12.7 \mathrm{~mm}$, TKA was higher at $79 \% \mathrm{MC}\left(650 \mathrm{~mm}^{2}\right)$ than at $121 \% \mathrm{MC}(462$ $\mathrm{mm}^{2}$ ) at $-20{ }^{\circ} \mathrm{C}$. This increased the effect of MC on WCT at higher sub-zero temperature, as it was previously explained, producing thicker chips at lower MC. However, TKA was higher in green $\operatorname{logs}\left(745 \mathrm{~mm}^{2}\right)$ compared to air-dried $\operatorname{logs}\left(532 \mathrm{~mm}^{2}\right)$ at $-10{ }^{\circ} \mathrm{C}$, which resulted in slightly thicker chips in the former than in the latter. The same behavior was found at a cutting width of $25.4 \mathrm{~mm}$. The number of knots also showed a positive effect on WCT. These results are in agreement with those reported previously by Cáceres et al. (2016, 2017) and by Grubîi et al. (2019). Overall, this confirms the importance of the knot characteristics on the chip size variation. The sapwood thickness also affected WCT, especially when transforming frozen logs. In fact, a thicker sapwood will promote the formation of thinner chips at sub-zero temperatures. This is in accordance with previous studies of Hernández and Lessard (1997).

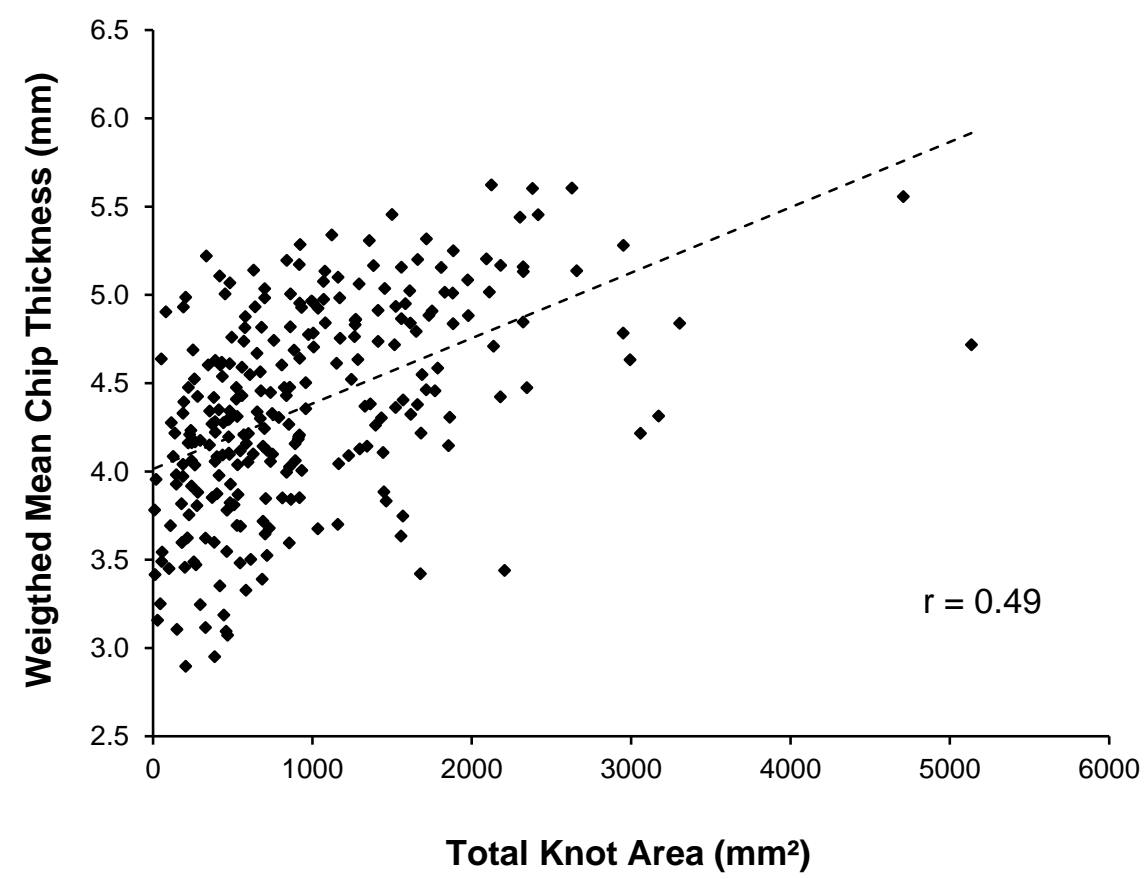

Fig. 5. Relationship between weighted mean chip thickness and total knot area of black spruce chips (all data pooled) 


\section{Multiple Linear Regression of WCT}

One of the goals of this study was to predict chip thickness for practical applications. Linear regression analyses were performed among WCT and the studied explanatory variables between $-20^{\circ} \mathrm{C}$ and $0{ }^{\circ} \mathrm{C}$ (Fig. 4). The statistical model showed that $\mathrm{CW}$, temperature $(T)$, TKA, TKN, and sapwood mean thickness (ST) were significant predictors of WCT $(\mathrm{WCT}=3.6+0.053 \mathrm{CW}+0.036 T+0.001 \mathrm{TKN}+0.00011 \mathrm{TKA}-$ $0.19 \mathrm{ST})$. This global fit model gave a coefficient of determination of $84.0 \%\left(\mathrm{R}^{2}\right)$ and coefficient of variation of $4.9 \%$. The regression showed the combined action of these variables to predict chip thickness. The $\mathrm{CW}$ was the most important variable with a positive effect and a contribution to the $\mathrm{R}^{2}$ of $50.4 \%$, followed by temperature with a contribution to the $\mathrm{R}^{2}$ of $27.1 \%$. Moreover, TKN and TKA had positive effects on WCT with contributions to the $\mathrm{R}^{2}$ of $3.6 \%$ and $1.5 \%$, respectively. Finally, ST had a negative effect and a contribution to the $\mathrm{R}^{2}$ of $0.9 \%$. The high coefficient of determination and the low coefficient of variation confirm that the regression model can be used for predictive purposes. However, at the present time the assessment of TKA and ST just before the log breakdown could represent an important challenge for the industry. Therefore, a second analysis was performed to predict WCT by removing these two parameters. The second model $(\mathrm{WCT}=3.27+0.056 \mathrm{CW}+0.037 \mathrm{~T}+0.016 \mathrm{TKN})$ explained $81.4 \%$ of the WCT variation, with a coefficient of variation of 5.0\%. The cutting widths had again the greatest contribution to the $\mathrm{R}^{2}$ of $52.2 \%$, followed by the temperature and TKN with contributions of $26.2 \%$ and $3.1 \%$ to the $\mathrm{R}^{2}$, respectively. This second model remains performant and could be used to effectively predict chip thickness. Accordingly, WCT can be adjusted by using primarily the $\mathrm{CW}$. The technology to measure the other concerned variables before processing the logs has been in the market for several years. An infrared camera could be used to measure the log temperature. In addition, the CT scan technology accurately recognizes knots and is already used in several sawmills to optimize log breakdown. Therefore, sawmills could take advantage of the given knowledge to better control chip thickness during fragmentation and thereby improving chip size uniformity and consistency. However, it is important to indicate that this regression did not use MC to predict WCT because its effect was significant only at $-20{ }^{\circ} \mathrm{C}$, which has been already explained. Therefore, the WCT prediction model would be less robust at higher sub-zero temperatures and thus the estimated WCT value would be less accurate.

\section{Domtar and Williams Chip Class Distributions}

Multivariate analysis of covariance for Domtar and Williams chip class distributions were performed to study the chip formation process as a whole. They took into account the existing dependences among the chip classes and showed that they were affected differently by $\mathrm{CW}$, temperature, and MC. Table 2 shows that log temperature and $\mathrm{CW}$ had the strongest effects (F-values) on the thickness (Domtar) and width/length (Williams) distributions. In addition, the significant effect of their interaction was also well represented in both distributions. However, the effect of MC, which was nested in each $\mathrm{CW}$, and the three-way interaction among temperature, $\mathrm{CW}$, and $\mathrm{MC}$ (Table 2) was poorly represented on the individual chip classes and in terms of chip volume (only fines, Table 3). Thus, no further discussion was given on them.

The compositional data approach that was applied did not allow comparisons of the real values of each class because it works with proportions. Therefore, univariate analyses of covariance were performed for each class of Domtar and Williams chip size distributions (Tables 3 and 4). The significant covariates obtained in the MANCOVAs were kept in each class analysis to observe their specific influence on each chip class. 
Table 3. F-Values Obtained from the ANCOVAs for each Domtar Chip Classes

\begin{tabular}{|c|c|c|c|c|c|}
\hline \multirow{2}{*}{$\begin{array}{l}\text { Source of } \\
\text { Variation }\end{array}$} & \multicolumn{5}{|c|}{ Domtar Chip Classes } \\
\hline & Fines & $\begin{array}{c}\text { Fragile } \\
\text { Chips }\end{array}$ & Accepts & Overthicks & Oversize \\
\hline TKA & $8.2^{* *}$ & $0.6 \mathrm{~ns}$ & $30.3^{* *}$ & $119.3^{* *}$ & $37.6^{* *}$ \\
\hline TKN & $6.1^{*}$ & $18.5^{\star *}$ & $2.3 \mathrm{~ns}$ & $15.4^{* *}$ & $0.1 \mathrm{~ns}$ \\
\hline$T$ & $103.8^{* \star}$ & $171.4^{\star *}$ & $92.7^{\star \star}$ & $39.8^{* *}$ & $1.6 \mathrm{~ns}$ \\
\hline CW & $12.4^{\star \star}$ & $281.2^{\star \star}$ & $64.9^{* *}$ & $133.0^{* \star}$ & $7.1^{\star \star}$ \\
\hline $\mathrm{T}^{*} \mathrm{CW}$ & $3.3^{*}$ & $4.7^{\star \star}$ & $13.8^{* *}$ & $3.4^{*}$ & $3.0^{*}$ \\
\hline$[\mathrm{MC}(\mathrm{CW})]$ & $23.0^{* *}$ & $0.7 \mathrm{~ns}$ & $0.1 \mathrm{~ns}$ & $1.5 \mathrm{~ns}$ & $2.4 \mathrm{~ns}$ \\
\hline $\mathrm{T}^{\star} \mathrm{MC}^{\star} \mathrm{CW}$ & $3.5^{\star \star}$ & $1.9 \mathrm{~ns}$ & $1.2 \mathrm{~ns}$ & $1.5 \mathrm{~ns}$ & $1.4 \mathrm{~ns}$ \\
\hline
\end{tabular}

Table 4. F-Values Obtained from the ANCOVAs for each Williams Chip Classes

\begin{tabular}{|c|c|c|c|c|c|}
\hline \multirow{2}{*}{$\begin{array}{l}\text { Source of } \\
\text { Variation }\end{array}$} & \multicolumn{5}{|c|}{ Williams Chip Classes } \\
\hline & Fines & Pin Chips & $9.5 \mathrm{~mm}$ & Accepts & $\geq 45 \mathrm{~mm}$ \\
\hline TKA & $6.4^{*}$ & $2.9 \mathrm{~ns}$ & $1.1 \mathrm{~ns}$ & $0.4 \mathrm{~ns}$ & $11.1^{\star \star}$ \\
\hline TKN & $5.8^{*}$ & $9.2^{*}$ & $0.1 \mathrm{~ns}$ & $2.4 \mathrm{~ns}$ & $0.4 \mathrm{~ns}$ \\
\hline $\mathrm{T}$ & $97.7^{* *}$ & $96.0^{* *}$ & $40.7^{\star \star}$ & $80.3^{* *}$ & $3.0^{*}$ \\
\hline CW & $34.5^{\star *}$ & $48.0^{* \star}$ & $63.7^{* *}$ & $76.4^{* *}$ & $7.2^{* *}$ \\
\hline $\mathrm{T}^{\star} \mathrm{CW}$ & $6.3^{* *}$ & $7.9^{* *}$ & $1.2 \mathrm{~ns}$ & $8.2^{* *}$ & $2.5 \mathrm{~ns}$ \\
\hline$[\mathrm{MC}(\mathrm{CW})]$ & $10.8^{* *}$ & $1.7 \mathrm{~ns}$ & $0.2 \mathrm{~ns}$ & $1.0 \mathrm{~ns}$ & $0.3 \mathrm{~ns}$ \\
\hline $\mathrm{T}^{*} \mathrm{MC} \mathrm{C}^{*} \mathrm{CW}$ & $1.0 \mathrm{~ns}$ & $1.6 \mathrm{~ns}$ & $0.3 \mathrm{~ns}$ & $0.8 \mathrm{~ns}$ & $0.7 \mathrm{~ns}$ \\
\hline
\end{tabular}

Domtar and Williams chip class distributions were significantly affected by TKA and TKN as covariates (Table 2). For Domtar distribution, TKA had a significant effect in all classes except for fragile chips. These classes altogether represented around $86 \%$ of the total chips (Table 3). The increase of TKA resulted in the increase of thicker chips (accepts, overthick, and oversize) and the decrease of thinner chips (fines). The total knot number had a significant effect on fines, fragile, and overthick classes, which represented $20 \%$ of chips (Tables 3 and 5). The effect of TKA on WCT was more relevant to that of TKN. This is in agreement with previous findings that established the importance of the number and size of knots on Domtar chip distribution (Cáceres et al. 2015, 2016, 2017). Total knot area and TKN affected in a lesser degree the width and length of chips. For Williams distribution, TKA affected significantly fines and $\geq 45 \mathrm{~mm}$ chip classes, which represents $3 \%$ of the total volume of chips. The total knot number had an influence on $9.5 \%$ of the chip volume coming from fines and pin chips (Tables 4 and 6). Therefore, the chip thickness was more sensitive to the presence and size of knots compared to the chip width/length.

As shown in Tables 3 and 4, all Domtar chip classes and most of the Williams chip classes including fines, pin chips, and accepts, showed a significant interaction of CW and temperature. These results are consistent with the MANCOVAs, showing that chip classes varied differently with temperature and cutting width (Table 2). The F-values showed that this interaction was stronger for the accept chips of both distributions. Figure 6 shows this interaction for the Williams accepts, which decrease as the temperature decreases below 0 ${ }^{\circ} \mathrm{C}$. The effect of temperature was more pronounced at the smaller $\mathrm{CW}$, which is explained by the higher volume of sapwood transformed into chips. 


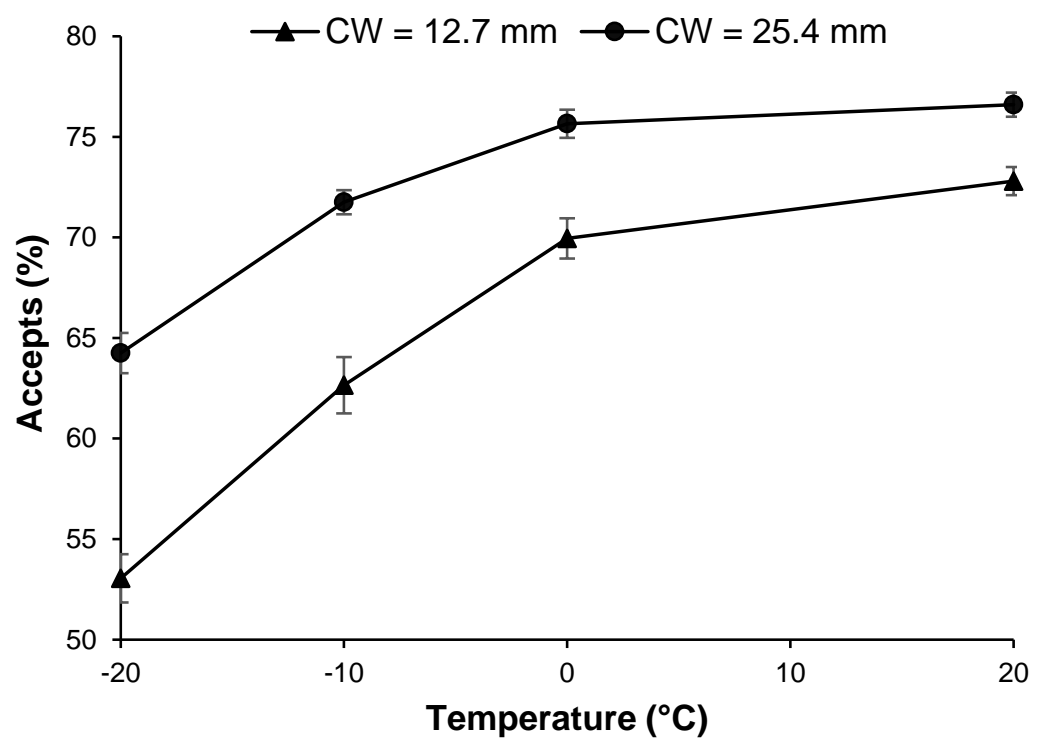

Fig. 6. Proportion of Williams acceptable chips as a function of temperature for two cutting widths (all chip MCs pooled)

Table 5. Mean Values of Domtar Chip Class Proportions and Weighted Mean Chip Thickness Obtained for Each Cutting Condition of Black Spruce

\begin{tabular}{|c|c|c|c|c|c|c|c|c|}
\hline $\begin{array}{l}\text { CW } \\
(\mathrm{mm})\end{array}$ & $\begin{array}{c}\text { Chip } \\
\text { MC (\%) }\end{array}$ & $\begin{array}{l}\text { Temper- } \\
\text { ature }\left({ }^{\circ} \mathrm{C}\right)\end{array}$ & Fines & $\begin{array}{c}\text { Fragile } \\
\text { Chips }\end{array}$ & Accepts & $\begin{array}{c}\text { Over- } \\
\text { thicks }\end{array}$ & $\begin{array}{l}\text { Over- } \\
\text { size }\end{array}$ & $\begin{array}{l}\text { WCT } \\
(\mathrm{mm})\end{array}$ \\
\hline \multirow{8}{*}{12.7} & \multirow{4}{*}{121} & -20 & $\begin{array}{c}2.08^{\mathrm{a}} \\
(0.20)^{\mathrm{a}, \mathrm{b}} \\
\end{array}$ & $\begin{array}{l}25.3 \\
(1.2)\end{array}$ & $\begin{array}{l}71.4 \\
(1.3)\end{array}$ & $\begin{array}{c}1.2 \\
(0.1) \\
\end{array}$ & $\begin{array}{c}0.03 \\
(0.03) \\
\end{array}$ & $\begin{array}{c}3.24 \\
(0.06) \\
\end{array}$ \\
\hline & & -10 & $\begin{array}{c}1.54 \\
(0.15)\end{array}$ & $\begin{array}{l}17.9 \\
(0.8)\end{array}$ & $\begin{array}{l}77.5 \\
(0.9)\end{array}$ & $\begin{array}{c}3.1 \\
(0.4)\end{array}$ & $\begin{array}{c}0.00 \\
(0.00)\end{array}$ & $\begin{array}{c}3.94 \\
(0.06)\end{array}$ \\
\hline & & 0 & $\begin{array}{c}0.92 \\
(0.08)\end{array}$ & $\begin{array}{l}14.4 \\
(0.4)\end{array}$ & $\begin{array}{l}81.3 \\
(0.7) \\
\end{array}$ & $\begin{array}{c}3.4 \\
(0.4)\end{array}$ & $\begin{array}{c}0.00 \\
(0.00)\end{array}$ & $\begin{array}{r}4.15 \\
(0.04) \\
\end{array}$ \\
\hline & & 20 & $\begin{array}{c}0.49 \\
(0.02)\end{array}$ & $\begin{array}{l}11.0 \\
(0.5)\end{array}$ & $\begin{array}{l}84.4 \\
(0.4)\end{array}$ & $\begin{array}{c}4.0 \\
(0.3)\end{array}$ & $\begin{array}{c}0.09 \\
(0.07)\end{array}$ & $\begin{array}{r}4.35 \\
(0.06)\end{array}$ \\
\hline & \multirow{4}{*}{79} & -20 & $\begin{array}{c}1.57 \\
(0.19)\end{array}$ & $\begin{array}{l}22.6 \\
(0.9)\end{array}$ & $\begin{array}{l}73.4 \\
(1.0)\end{array}$ & $\begin{array}{c}2.3 \\
(0.2)\end{array}$ & $\begin{array}{c}0.12 \\
(0.06)\end{array}$ & $\begin{array}{c}3.56 \\
(0.04)\end{array}$ \\
\hline & & -10 & $\begin{array}{c}1.11 \\
(0.16) \\
\end{array}$ & $\begin{array}{l}18.1 \\
(0.9)\end{array}$ & $\begin{array}{l}77.9 \\
(1.0)\end{array}$ & $\begin{array}{c}2.8 \\
(0.3) \\
\end{array}$ & $\begin{array}{c}0.07 \\
(0.04) \\
\end{array}$ & $\begin{array}{r}3.88 \\
(0.06) \\
\end{array}$ \\
\hline & & 0 & $\begin{array}{c}0.68 \\
(0.08)\end{array}$ & $\begin{array}{l}14.5 \\
(0.5)\end{array}$ & $\begin{array}{l}80.7 \\
(0.6)\end{array}$ & $\begin{array}{c}4.0 \\
(0.4)\end{array}$ & $\begin{array}{c}0.19 \\
(0.10)\end{array}$ & $\begin{array}{c}4.22 \\
(0.06)\end{array}$ \\
\hline & & 20 & $\begin{array}{c}0.38 \\
(0.02)\end{array}$ & $\begin{array}{l}11.8 \\
(0.5)\end{array}$ & $\begin{array}{l}83.7 \\
(0.5)\end{array}$ & $\begin{array}{c}4.1 \\
(0.3)\end{array}$ & $\begin{array}{c}0.02 \\
(0.02)\end{array}$ & $\begin{array}{c}4.35 \\
(0.05)\end{array}$ \\
\hline \multirow{8}{*}{25.4} & \multirow{4}{*}{103} & -20 & $\begin{array}{c}1.94 \\
(0.21)\end{array}$ & $\begin{array}{l}15.4 \\
(0.9)\end{array}$ & $\begin{array}{l}78.2 \\
(0.8)\end{array}$ & $\begin{array}{c}4.4 \\
(0.6)\end{array}$ & $\begin{array}{c}0.06 \\
(0.03)\end{array}$ & $\begin{array}{c}4.10 \\
(0.10)\end{array}$ \\
\hline & & -10 & $\begin{array}{c}0.95 \\
(0.07)\end{array}$ & $\begin{array}{l}10.6 \\
(0.4)\end{array}$ & $\begin{array}{l}80.9 \\
(0.7)\end{array}$ & $\begin{array}{c}7.2 \\
(0.6)\end{array}$ & $\begin{array}{c}0.30 \\
(0.09)\end{array}$ & $\begin{array}{r}4.80 \\
(0.07) \\
\end{array}$ \\
\hline & & 0 & $\begin{array}{c}0.75 \\
(0.06)\end{array}$ & $\begin{array}{c}8.5 \\
(0.5)\end{array}$ & $\begin{array}{l}82.8 \\
(0.7)\end{array}$ & $\begin{array}{c}7.8 \\
(0.5)\end{array}$ & $\begin{array}{c}0.08 \\
(0.03)\end{array}$ & $\begin{array}{c}5.05 \\
(0.06)\end{array}$ \\
\hline & & 20 & $\begin{array}{c}0.47 \\
(0.02)\end{array}$ & $\begin{array}{l}7.0 \\
(0.3)\end{array}$ & $\begin{array}{l}84.8 \\
(0.9)\end{array}$ & $\begin{array}{c}7.5 \\
(0.7)\end{array}$ & $\begin{array}{c}0.21 \\
(0.09)\end{array}$ & $\begin{array}{c}5.10 \\
(0.06)\end{array}$ \\
\hline & \multirow{4}{*}{67} & -20 & $\begin{array}{c}0.95 \\
(0.07) \\
\end{array}$ & $\begin{array}{l}13.6 \\
(0.6) \\
\end{array}$ & $\begin{array}{l}79.4 \\
(0.6) \\
\end{array}$ & $\begin{array}{c}5.6 \\
(0.4) \\
\end{array}$ & $\begin{array}{c}0.42 \\
(0.31) \\
\end{array}$ & $\begin{array}{r}4.38 \\
(0.06) \\
\end{array}$ \\
\hline & & -10 & $\begin{array}{c}0.79 \\
(0.08)\end{array}$ & $\begin{array}{l}11.3 \\
(0.5) \\
\end{array}$ & $\begin{array}{l}80.7 \\
(0.8) \\
\end{array}$ & $\begin{array}{c}6.9 \\
(0.8) \\
\end{array}$ & $\begin{array}{c}0.31 \\
(0.12) \\
\end{array}$ & $\begin{array}{c}4.71 \\
(0.09) \\
\end{array}$ \\
\hline & & 0 & $\begin{array}{c}0.55 \\
(0.04)\end{array}$ & $\begin{array}{c}9.3 \\
(0.3)\end{array}$ & $\begin{array}{l}82.3 \\
(0.5)\end{array}$ & $\begin{array}{c}7.5 \\
(0.5)\end{array}$ & $\begin{array}{c}0.34 \\
(0.13)\end{array}$ & $\begin{array}{r}4.96 \\
(0.06)\end{array}$ \\
\hline & & 20 & $\begin{array}{c}0.37 \\
(0.02)\end{array}$ & $\begin{array}{c}7.4 \\
(0.3)\end{array}$ & $\begin{array}{l}84.9 \\
(0.5)\end{array}$ & $\begin{array}{c}6.8 \\
(0.5)\end{array}$ & $\begin{array}{c}0.60 \\
(0.19)\end{array}$ & $\begin{array}{c}4.99 \\
(0.07)\end{array}$ \\
\hline
\end{tabular}

${ }^{a}$ Means of 15 replicates; ${ }^{b}$ Numbers in parentheses are the standard errors of the mean 
The total volume of removed material at $12.7 \mathrm{~mm}$ of $\mathrm{CW}$ corresponded to $98 \%$ of sapwood, which was reduced to $76 \%$ at $25.4 \mathrm{~mm}$ of $\mathrm{CW}$. Moreover, the greater amount of ice present in the sapwood compared to the heartwood lead to a higher sensitivity to the temperature decrease below $0{ }^{\circ} \mathrm{C}$ for the smaller $\mathrm{CW}$. The weighted mean chip thickness was directly related to the proportion of accepts (Figs. 4 and 6), because it concentrated the highest volume of chips. Therefore, the adjustment of the nominal chip thickness in an adequate manner is essential to avoid an important decrease of the accept chips at temperatures below zero.

The mean values of the Domtar and Williams chip classes by cutting width, moisture content, and temperature are summarized in Tables 5 and 6. Chip classes are expressed as percent weight of the total chips. The temperature affected all Domtar classes, except for oversize chips (about $0.2 \%$ of chips total volume). As temperature increased, the proportion of smaller chip classes decreased and, hence the bigger ones increased.

Table 6. Mean Values of Williams Chip Class Proportions Obtained for Each Cutting Condition of Black Spruce

\begin{tabular}{|c|c|c|c|c|c|c|c|}
\hline $\begin{array}{c}\text { CW } \\
(\mathrm{mm})\end{array}$ & $\begin{array}{l}\text { Chip } \\
\text { MC (\%) }\end{array}$ & $\begin{array}{l}\text { Temper- } \\
\text { ature }\left({ }^{\circ} \mathrm{C}\right)\end{array}$ & Fines & $\begin{array}{l}\text { Pin } \\
\text { Chips }\end{array}$ & $9.5 \mathrm{~mm}$ & Accepts & $\geq 45 \mathrm{~mm}$ \\
\hline \multirow{8}{*}{12.7} & \multirow{4}{*}{121} & -20 & $\begin{array}{c}5.99^{\mathrm{a}} \\
(0.69)^{\mathrm{b}}\end{array}$ & $\begin{array}{l}12.0 \\
(0.6)\end{array}$ & $\begin{array}{l}29.8 \\
(0.8)\end{array}$ & $\begin{array}{l}52.1 \\
(1.8)\end{array}$ & $\begin{array}{c}0.00 \\
(0.00)\end{array}$ \\
\hline & & -10 & $\begin{array}{c}4.64 \\
(0.45)\end{array}$ & $\begin{array}{c}9.6 \\
(0.5)\end{array}$ & $\begin{array}{l}24.1 \\
(1.0)\end{array}$ & $\begin{array}{l}61.7 \\
(1.9)\end{array}$ & $\begin{array}{c}0.00 \\
(0.00)\end{array}$ \\
\hline & & 0 & $\begin{array}{c}2.72 \\
(0.26)\end{array}$ & $\begin{array}{c}6.9 \\
(0.3)\end{array}$ & $\begin{array}{l}20.9 \\
(1.1)\end{array}$ & $\begin{array}{l}69.5 \\
(1.0)\end{array}$ & $\begin{array}{c}0.00 \\
(0.00)\end{array}$ \\
\hline & & 20 & $\begin{array}{c}1.06 \\
(0.06)\end{array}$ & $\begin{array}{c}4.8 \\
(0.2)\end{array}$ & $\begin{array}{l}21.6 \\
(0.8)\end{array}$ & $\begin{array}{l}72.5 \\
(0.9)\end{array}$ & $\begin{array}{c}0.06 \\
(0.05)\end{array}$ \\
\hline & \multirow{4}{*}{79} & -20 & $\begin{array}{c}4.45 \\
(0.52)\end{array}$ & $\begin{array}{l}11.9 \\
(0.6)\end{array}$ & $\begin{array}{l}29.6 \\
(0.7)\end{array}$ & $\begin{array}{l}54.0 \\
(1.6)\end{array}$ & $\begin{array}{c}0.00 \\
(0.00)\end{array}$ \\
\hline & & -10 & $\begin{array}{c}3.20 \\
(0.48)\end{array}$ & $\begin{array}{c}8.6 \\
(0.7)\end{array}$ & $\begin{array}{l}24.7 \\
(1.1)\end{array}$ & $\begin{array}{l}63.6 \\
(2.1)\end{array}$ & $\begin{array}{c}0.00 \\
(0.00)\end{array}$ \\
\hline & & 0 & $\begin{array}{c}1.90 \\
(0.28)\end{array}$ & $\begin{array}{c}6.5 \\
(0.6)\end{array}$ & $\begin{array}{l}21.3 \\
(1.2)\end{array}$ & $\begin{array}{l}70.4 \\
(1.7)\end{array}$ & $\begin{array}{c}0.03 \\
(0.03)\end{array}$ \\
\hline & & 20 & $\begin{array}{c}0.85 \\
(0.04)\end{array}$ & $\begin{array}{c}4.2 \\
(0.2)\end{array}$ & $\begin{array}{l}21.9 \\
(0.9)\end{array}$ & $\begin{array}{l}73.1 \\
(1.0)\end{array}$ & $\begin{array}{c}0.00 \\
(0.00)\end{array}$ \\
\hline \multirow{8}{*}{25.4} & \multirow{4}{*}{103} & -20 & $\begin{array}{c}3.65 \\
(0.44)\end{array}$ & $\begin{array}{c}8.6 \\
(0.6)\end{array}$ & $\begin{array}{l}23.5 \\
(0.7)\end{array}$ & $\begin{array}{l}64.2 \\
(1.6)\end{array}$ & $\begin{array}{c}0.02 \\
(0.02)\end{array}$ \\
\hline & & -10 & $\begin{array}{c}2.23 \\
(0.15)\end{array}$ & $\begin{array}{c}6.1 \\
(0.2)\end{array}$ & $\begin{array}{l}19.1 \\
(0.6)\end{array}$ & $\begin{array}{l}72.5 \\
(0.7)\end{array}$ & $\begin{array}{c}0.11 \\
(0.08)\end{array}$ \\
\hline & & 0 & $\begin{array}{c}1.41 \\
(0.16)\end{array}$ & $\begin{array}{c}4.7 \\
(0.4)\end{array}$ & $\begin{array}{l}17.5 \\
(1.1)\end{array}$ & $\begin{array}{l}76.3 \\
(1.5)\end{array}$ & $\begin{array}{c}0.13 \\
(0.06)\end{array}$ \\
\hline & & 20 & $\begin{array}{c}1.01 \\
(0.08)\end{array}$ & $\begin{array}{c}4.6 \\
(0.3)\end{array}$ & $\begin{array}{l}18.5 \\
(0.7)\end{array}$ & $\begin{array}{l}75.6 \\
(0.8)\end{array}$ & $\begin{array}{c}0.35 \\
(0.13)\end{array}$ \\
\hline & \multirow{4}{*}{67} & -20 & $\begin{array}{c}2.74 \\
(0.35)\end{array}$ & $\begin{array}{c}8.5 \\
(0.4)\end{array}$ & $\begin{array}{l}24.4 \\
(0.8)\end{array}$ & $\begin{array}{l}64.3 \\
(1.3)\end{array}$ & $\begin{array}{c}0.08 \\
(0.06)\end{array}$ \\
\hline & & -10 & $\begin{array}{c}2.07 \\
(0.22)\end{array}$ & $\begin{array}{c}6.5 \\
(0.4)\end{array}$ & $\begin{array}{l}20.3 \\
(0.5)\end{array}$ & $\begin{array}{l}71.0 \\
(0.9)\end{array}$ & $\begin{array}{c}0.11 \\
(0.07)\end{array}$ \\
\hline & & 0 & $\begin{array}{c}1.48 \\
(0.15)\end{array}$ & $\begin{array}{c}5.1 \\
(0.2)\end{array}$ & $\begin{array}{l}18.0 \\
(0.6)\end{array}$ & $\begin{array}{l}75.0 \\
(0.8)\end{array}$ & $\begin{array}{c}0.39 \\
(0.11)\end{array}$ \\
\hline & & 20 & $\begin{array}{c}0.74 \\
(0.04)\end{array}$ & $\begin{array}{c}3.7 \\
(0.2)\end{array}$ & $\begin{array}{l}17.7 \\
(0.8)\end{array}$ & $\begin{array}{l}77.6 \\
(0.9)\end{array}$ & $\begin{array}{c}0.32 \\
(0.10)\end{array}$ \\
\hline
\end{tabular}

When transforming logs at the smaller $\mathrm{CW}$, as the temperature increased from -20 ${ }^{\circ} \mathrm{C}$ to $20{ }^{\circ} \mathrm{C}$, the fragile fraction decreased drastically from 23.9 to $11.4 \%$ and the accepts increased from 72.4 to $84.1 \%$. Similarly, when transforming logs with the larger CW (25.4 $\mathrm{mm}$ ), as the temperature increased from $-20^{\circ} \mathrm{C}$ to $20^{\circ} \mathrm{C}$, the fragile fraction decreased from 
14.5 to $7.2 \%$ and the accepts increased from 78.8 to $84.9 \%$. These comparisons were done when values of both MCs were pooled. Similar results were found with the Williams chip classes, in which the fines, pin chips, and $9.5 \mathrm{~mm}$ classes decreased as temperature increased in contrast to the increase in the accepts and over $45-\mathrm{mm}$ classes. The amount of fines was approximately four times higher at $-20{ }^{\circ} \mathrm{C}$ than at $20{ }^{\circ} \mathrm{C}$ for the cutting width of $12.7 \mathrm{~mm}$ and three times higher for the cutting width of 25.4. Pin chips increased from $4.5 \%$ to $12.0 \%$ at $12.7 \mathrm{~mm} \mathrm{CW}$ and from $4.2 \%$ to $8.6 \%$ at $25.4 \mathrm{~mm} \mathrm{CW}$, as temperature decreased from 20 to $-20{ }^{\circ} \mathrm{C}$. The strong relationships between fines and pin chips with sub-zero temperatures are in agreement with the results reported in previous studies (Wallace et al. 1992; Hernández and Quirion 1993; Hernández and Boulanger 1997; Hernández and Lessard 1997).

Even though the fines represent only a little fraction of the total volume of chips, these particles, together with the pin chips, have great impacts in the pulp cooking processes (Hart 2009). Each pulp and paper mill has specific chip quality requirements for its pulping process (mechanical and/or chemical pulping). Domtar and Williams chip class distributions have to fit with these requirements. For example, in a thermomechanical pulp process, a limit of $8 \%$ of rejects of the total chip volume (fines and pin chips) is imposed considering a maximum of $1 \%$ of fines (Bélanger and Savard 2016). The authors' results showed that this limit was respected when processing logs at $20^{\circ} \mathrm{C}$ and it was exceeded when processing logs at temperatures below $0{ }^{\circ} \mathrm{C}$. A temperature decrease from 20 to -20 ${ }^{\circ} \mathrm{C}$ increased the proportion of rejects from 5.5 to $17.7 \%$ and from 5.0 to $11.8 \%$ at a cutting width of 12.7 and $25.4 \mathrm{~mm}$, respectively.

Overall, the log temperature should be taken into consideration to adjust the cutting parameters of the chipper-canter to minimize the amount of smaller size chips and thus avoiding the penalties imposed by pulp industries. For instance, Hernández and Boulanger (1997) found that a faster cutting speed for a given chip length produced thinner chips. Under the specific cutting conditions used here, decreasing the cutting speed in winter would increase the WCT and reduce the amount of rejects. Therefore, changing cutting speed as a function of temperature and cutting width can be used to improve chip size uniformity. However, reducing the cutting speed would negatively affect the sawmill productivity. Another possibility could be to use different knives depending on log temperature. Grubîi et al. (2019) found that a higher inclination angle of the chipping knife would result in thicker chips. Thus, using this type of knife during winter could again reduce the amount of rejects. The results also indicate that it could be advantageous to keep the logs harvested during fall and stored in the yard for a certain time (up to 62\% sapwood MC, Table 1). This air-drying of logs would moderately reduce their MC and thus lessen the negative effect of coldest sub-zero temperatures $\left(\geq-20^{\circ} \mathrm{C}\right)$ on WCT. However, further studies are required to evaluate the effect of air-drying logs for longer periods (sapwood $\mathrm{MC} \leq 62 \%$ ) on chip size distribution, especially at colder sub-zero temperatures.

\section{CONCLUSIONS}

1. The cutting width had an important effect on the size distribution of black spruce chips produced by a chipper-canter. Smaller CWs resulted in thinner chips and higher proportions of small particles.

2. Chip size was significantly affected by the temperature and in a slighter degree by the moisture content of the logs. Mean chip thickness and accept chips were generally similar at temperatures between 0 and $20^{\circ} \mathrm{C}$, and significantly decreased as temperature decreased below $0{ }^{\circ} \mathrm{C}$. This effect appeared related to changes in the mechanical properties of wood due to the temperature variation. Moreover, the effect of 
temperature on WCT under frozen conditions varied with the moisture content of logs. In general, the storage of logs under harsh cold conditions $\left(-20{ }^{\circ} \mathrm{C}\right)$, enabling their progressive air-drying down to a certain level of sapwood moisture content $(\geq 62 \%$ MC), could increase WCT and lead to better chip quality.

3. Regression equations were established to predict the chip thickness. These models give useful information to adjust the cutting parameters of chipper-canters working under similar conditions to effectively maintain the target WCT throughout the year.

\section{ACKNOWLEDGMENTS}

Funding for this project was provided by the Natural Sciences and Engineering Research Council of Canada (NSERC) and by DK-SPEC Inc. The authors are grateful for the support of Wassim Kharrat, Bruna Ugulino, and Irsan Alipraja during the laboratory experiences. The authors also thank Daniel Bourgault, Félix Pedneault, Luc Germain, and Jean Ouellet for their technical assistance.

\section{REFERENCES CITED}

Aitchison, J. (1982). "The statistical-analysis of compositional data," J. Royal Stat. Soc. Ser. B-Met. 44(2), 139-177. DOI: 10.1111/j.2517-6161.1982.tb01195.x

ASTM D2395-17 (2017). "Standard test methods for density and specific gravity (relative density) of wood and wood-based materials," ASTM International, West Conshohocken, PA, USA.

ASTM D4442-16 (2016). "Standard test methods for direct moisture content measurement of wood and wood-based materials," ASTM International, West Conshohocken, PA, USA.

Bélanger, L., and Savard, G. (2016). "Maîtrise de la Granulométrie des copeaux our le procédé de papier thermomécanique [Control of chip particle size for the thermomechanical paper process]," in: Produits Forestiers Résolu, Quebec, Canada.

Bergman, T. (1985). "Chip quality - essentials and improvements," in: Proceedings of Pulping Conference, TAPPI Press, Hollywood, FL, USA, pp. 31-36.

Cáceres, C. B., Hernández, R. E., and Koubaa, A. (2015). "Effects of the cutting pattern and $\log$ provenance on size distribution of black spruce chips produced by a chippercanter," Eur. J. Wood. Wood. Prod. 73(3), 357-368. DOI:10.1007/s00107-015-0894-0

Cáceres, C. B., Hernández, R. E., and Koubaa, A. (2016). "Effects of log position in the stem and cutting width on size distribution of black spruce chips produced by a chipper-canter," Wood. Fiber Sci. 48(1), 25-42.

Cáceres, C. B., Hernández, R. E., and Koubaa, A. (2017). "Effects of log position in the stem and commercial thinning on jack pine chip dimensions produced by a chippercanter," Eur. J. Wood. Wood. Prod. 75(3), 359-373. DOI:10.1007/s00107-016-1062-x

Conseil de l'Industrie Forestière du Québec (CIFQ) (2014). "Statistiques," Quebec Forest Industry Council, (http://www.cifq.com/documents/file/qd3872-cifqdocumentstatistique2014-lr.pdf), Accessed 12 April 2021.

Delisle, J. F. (2019). "Ressources et industries forestières du Québec, portrait statistique 2019 [Quebec forest resources and industries, 2019. A statistical portrait]," (https://mffp.gouv.qc.ca/wp-content/uploads/PortraitStatistique_2019.pdf), Accessed 14 April 2021.

Feiner, J. H., and Gallay, W. (1962). "The effect of chip thickness on sulphite pulp yield and quality," Pulp. Pap.-Canada 63(9), T435-T441. 
Gao, X., Zhuang, S., Jin, J., and Cao, P. (2015). "Bonded water content and pore size distribution in swollen cell walls determined by NMR technology," BioResources 10(4), 8208-8224. DOI: 10.15376/biores.10.4.8208-8224

Grubîi, V., Cáceres, C. B., Hernández, R. E., and Blais, C. (2019). "Effect of chipping edge inclination angle on size distribution of pulp chips produced by a chippercanter," Wood. Fiber Sci. 51(4), 402-415. DOI: 10.22382/wfs-2019-038

Guo, Y., Zhang, M., Xiao, Z., Chen, H., and Xie, Y. (2018). "Vaporization heat of bound water in wood chemically modified via grafting and crosslinking patterns by DSC and NMR analysis," Holzforschung 72(12), 1043-1049. DOI: 10.1515/hf-2017-0210

Hart, P. W. (2009). "Seasonal variations in wood: Perceived and real impacts on pulp yield," TAPPI J. 7(3), 4-8.

Hartler, N., and Stade, Y. (1979). "Chip specifications for various pulping processes," in: Chip Quality Monograph, J. V. Hatton (ed.), Joint Textbook Committee of the Paper Industry, Atlanta, GA, USA, pp. 273-301.

Hatton, J. V., and Keays, J. L. (1973). "Effect of chip geometry and moisture on yield and quality of kraft pulps from western hemlock and black spruce," Pulp. Pap.-Canada 74(1), 79-87.

Hernández, R. E., and Boulanger, J. (1997). "Effect of the rotation speed on the size distribution of black spruce pulp chips produced by a chipper-canter," Forest Prod. J. 47(4), 43-49.

Hernández, R. E., and Lessard, J. (1997). "Effect of cutting width and cutting height on the size distribution of black spruce pulp chips produced by a chipper-canter," Forest Prod. J. 47(3), 89-95.

Hernández, R. E., Passarini, L., and Koubaa, A. (2014). "Effects of temperature and moisture content on selected wood mechanical properties involved in the chipping process," Wood Sci. Technol. 48(6), 1281-1301. DOI: 10.1007/s00226-014-0673-9

Hernández, R. E., and Quirion, B. (1993). "Effect of a chipper-canter knife clamp on the quality of chips produced from black spruce," Forest Prod. J. 43(9), 8-14.

Hernández, R. E., and Quirion, B. (1995). "Effect of knife clamp, log diameter, and species on the size distribution of pulp chips produced by a chipper-canter," Forest Prod. J. 45(7-8), 83-90.

Hoekstra, P. L., Veal, M. A., Lee, P. F., and Sinkey, J. D. (1983). "The effects of chip size on mechanical pulp properties and energy-consumption," TAPPI J. 66, 119-122.

Jozsa, L. A., and Middleton, G. R. (1994). A Discussion of Wood Quality Attributes and Their Practical Implications, Forintek Canada Corporation, Vancouver, Canada.

Kharrat, W., Hernández, R. E., Cáceres, C. B., and Blais, C. (2021). "Influence of radial force and rake angle on ring debarking efficiency of frozen and unfrozen black spruce logs," Eur. J. Wood. Wood. Prod. 79(3), 629-643. DOI: 10.1007/s00107-020-01640-8

Koran, Z. (1979). "Tensile properties of spruce under different conditions," Wood Fiber 11(1), 38-49.

Kuljich, S., Hernández, R. E., and Blais, C. (2017). "Effects of the cutterhead diameter and log infeed position on size distribution of pulp chips produced by a chippercanter," Eur. J. Wood. Wood. Prod. 75(5), 747-760. DOI:10.1007/s00107-016-1150-y

Li, J., Ma, E., and Yang, T. (2019). "Differences between hygroscopicity limit and cell wall saturation investigated by LF-NMR on Southern pine (Pinus spp.)," Holzforschung 73(10), 911-921. DOI: 10.1515/hf-2018-0257

Lönnberg, B., and Robertsén, L. (1986). "Significance of chip thickness in CRMP and RMP: A laboratory study with pine chips," Pap. Puu-Pap. Tim. 68(1), 36-41.

Miles, P. D., and Smith, W. B. (2009). Specific Gravity and Other Properties of Wood and Bark for 156 Tree Species Found in North America (Research Note NRS-38), United States Department of Agriculture: Forest Service, Philadelphia, PA, USA. 
Mishiro, A., and Asano, I. (1984). "Mechanical properties of wood at low temperatures. Effect of moisture content and temperature on the bending properties of wood. II. Moisture content beyond the fiber-saturation point," Mokuzai Gakkaishi 30(4), 277286.

Mishiro, A. (1990). "Effect of freezing treatments on the bending properties of wood," Bull. Tokyo Univ. For. 82, 177-189.

Murnighan, B. (2018). "Secteur des pâtes et papiers de l'est du Canada: Transition industrielle en période d'incertitude [Eastern Canadian pulp and paper sector: Industrial transition in uncertain times]," in: Conférence sur la Politique Salariale d'Unifor [Unifor Montreal Salary Policy Conference], Montreal, Canada, pp. 57.

NRCAN (2020). "The state of Canada's forests 2020," Natural Resources Canada, (https://d1ied5g1xfgpx8.cloudfront.net/pdfs/40219.pdf), Accessed 12 April 2021.

Olson, D., Hatton, J. V., and Hunt, K. (1980). "Effect of chip thickness in kraftanthraquinone pulping of trembling aspen," TAPPI J. 63(12), 109-110.

Petrenko, V. F., and Whitworth, R. W. (2002). "Physics of ice," Oxford Scholarship Online,

(https://oxford.universitypressscholarship.com/view/10.1093/acprof:oso/9780198518 945.001.0001/acprof-9780198518945), Accessed 12 April 2021. DOI: 10.1093/acprof:oso/9780198518945.003.0008

Pulkki, R. (1991). A Literature Synthesis on the Effects of Wood Quality in the Manufacture of Pulp and Paper (Wood Harvesting Tech Note TN-171), Forest Engineering Research Institute of Canada, Vancouver, Canada.

Schulson, E. M. (2001). "Brittle failure of ice," Eng. Fract. Mech. 68(17-18), 1839-1887. DOI: $10.1016 / \mathrm{S} 0013-7944(01) 00037-6$

Quebec Government (2018). "Le climat du Québec, normales climatiques 1981-2010 [The climate of Quebec, normal climatic 1981-2010]," Ministère du Développement Durable, Environnement et Lutte contre les changements climatiques [Ministry of Sustainable Development, Environment and Fight Against Climate Change], (https://www.environnement.gouv.qc.ca/climat/normales/index.asp), Accessed 12 April 2021.

Telkki, V., Yliniemi, M., and Jokisaari J. (2013). "Moisture in softwoods: Fiber saturation point, hydroxyl site content, and the amount of micropores as determined from NMR relaxation time distributions," Holzforschung 67(3), 291-300. DOI: 10.1515/hf-2012-0057

Tikka, P., Kovasin, K., and Tahkanen, H. (1993). "Chip thickness vs kraft pulping performance. 2. Effect of chip thickness screening on cooking, oxygen delignification and bleaching of softwood kraft batch pulp," in: TAPPI Proceedings of Pulping Conference, Atlanta, GA, USA, pp. 833-838.

Tong, Q., Duchesne, I., Belley, D., Beaudoin, M., and Swift, E. (2013). "Characterization of knots in plantation white spruce," Wood. Fiber Sci. 45(1), 84-97.

Torgovnikov, G. I. (1993). "Dielectric properties of wood-based materials," in: Dielectric Properties of Wood and Wood-based Materials, Springer, Berlin, Heidelberg, pp. 135-159.

Trzcianowska, M., Beaudoin, D., and LeBel, L. (2019). "Current practices in log yard design and operations in the province of Quebec, Canada," Forest Prod. J. 69(4), 248-259. DOI: 10.13073/FPJ-D-19-00018

Wallace, R., Stuart, W. B., and Starling, R. (1992). "The effects of temperature on fines and pin chip production," in: TAPPI Proceedings of 1992 Pulping Conference, Boston, MA, USA, pp. 477-480.

Zhang, S. Y., and Koubaa, A. (2008). Softwoods of Eastern Canada: Forest Ecology, Characteristics, Processing and Uses, Forintek Canada Corporation, Quebec, Canada. 
Zhao, L., Jiang, J., Lu, J., and Zhan, T. (2015). "Flexural property of wood in low temperature environment," Cold Reg. Sci. Technol. 116, 65-69. DOI:

10.1016/j.coldregions.2015.04.001

Article submitted: April 15, 2021; Peer review completed: July 3, 2021; Revised version received and accepted: August 5, 2021; Published: August 11, 2021.

DOI: $10.15376 /$ biores.16.4.6684-6704 